\title{
Biomedical Applications of Nanofibers
}

\author{
A. Ghajarieh ${ }^{a}$, S. Habibi ${ }^{b, *}$, and A. Talebian ${ }^{b}$ \\ ${ }^{a}$ Young Researchers and Elite Club, Department of Textile Engineering, Yadegar-e-Imam Khomeini (RAH) Shahr-e Rey \\ Branch, Islamic Azad University, Tehran, 1815163111 Iran \\ ${ }^{b}$ Department of Textile Engineering, Islamic Azad University, Yadegar-e-Imam Khomeini (RAH) Shahr-e Rey Branch, \\ Tehran, 1815163111 Iran \\ *e-mail:sima.habibi@gmail.com
}

Received April 20, 2020; revised June 24, 2021; accepted June 24, 2021

\begin{abstract}
The idea of creating replacement for damaged or diseased tissue, which will mimic the physiological conditions and simultaneously promote regeneration by patients' own cells, has been a major challenge in the biomedicine for more than a decade. Therefore, nanofibers are a promising solution to address these challenges. Nanofiber technology is an exciting area attracting the attention of many researchers as a potential solution to these current challenges in the biomedical field such as burn and wound care, organ repair, and treatment for osteoporosis and various diseases. Nanofibers mimic the porous topography of natural extracellular matrix (ECM), hence they are advantageous for tissue regeneration . In biomedical engineering, electrospinning exhibits advantages as a tissue engineering scaffolds producer, which can make appropriate resemblance in physical structure with ECM. This is because of the nanometer scale of ECM fibrils in diameter, which can be mimicked by electrospinning procedure as well as its porous structure. In this review, the applications of nanofibers in various biomedical areas such as tissue engineering, wound dressing and facemask, are summarized. It provides opportunities to develop new materials and techniques that improve the ability for developing quick, sensitive and reliable analytical techniques.
\end{abstract}

Keywords: electrospinning, nanofiber, tissue engineering, wound dressing, facemask

DOI: $10.1134 / \mathrm{S} 1070427221070016$

\section{INTRODUCTION}

Millions of patients worldwide suffer from failures of various organs such as liver and heart. These patients will greatly benefit from advanced tissue regeneration technologies, which can promote restoration of the failing organ functions, or facilitate improved healing after organ transplantation. Another sector that has experienced even more rapid growth is the pharmaceutical sector. The search for more effective and controlled carrier for various drugs for curing some of the world's most threatening diseases, such as cancer [1]. Nowadays, nanofiber tissue-engineered scaffolds are considered as a satisfactory solution to aid the health and quality of life for millions of patients worldwide with end-stage organ failure or tissue loss [2]. The biocompatibility of scaffold materials actively participates in the signaling process for the requirement of safe deg- radation and also provides a substratum for cell migration into the defect sites of the tissue [3]. Due to the organized porous fiberous architectures and similarity of nanofibers to natural biological tissues, they can create a unique class of materials for many reasons; surface area and surface energy are much higher for nanofibers compared to bulk materials, which allows enhanced adhesion with cells, proteins, and drugs. Indeed, many in vitro studies on nanofibrous wound dressings, tissue engineering scaffolds and facemasks have shown that they can outperform their micro or macrometric scale counterparts, even when they are composed of the same material [4]. Many techniques have been employed to fabricate nanofiber, including template synthesis, self-assembly, temperatureinduced phase separation, freeze-drying, electrospinning, etc. Among these techniques, electrospinning is 


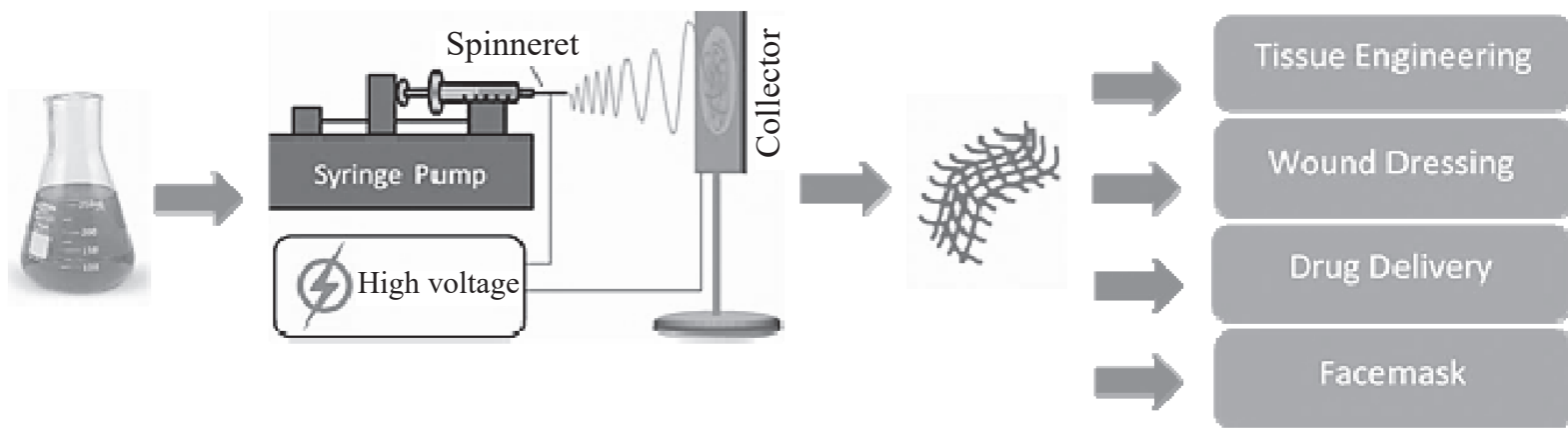

Fig. 1. Scheme of nanofiber preparation from polymer solution by electrospinning and their potential use in biomedical field [1].

a versatile and simple method that is most applied in regenerative medical application [3]. The biomedical field can be classified into three groups, usage of nanofibers as tissue scaffolds, wound dressings and facemasks (Fig. 1) [5-7]. Without any doubt, nanofibers are a unique class of materials, since on the nanometric level they provide a biomimetic environment, on the micrometric level three-dimensional architecture with the desired surface properties of the intended application within the body, while on the macrometric scale mechanical strength and physiological acceptability
[1]. This review discusses the electrospinning method and nanofibers impressionable properties by changing electrospinning parameters. There are many applications for electrospun tissue-engineered scaffolds, that here we introduced some of them and investigated some recent works on each of them. Classification of electrospun nanofibers based on their functional medical applications such as Wound dressing, Facemask, Vascular tissue engineering, Bone tissue engineering, Nerve tissue engineering, Skin tissue engineering and Cartilage tissue engineering.

Table 1. Affecting parameters on morphology of electrospun polymer nanofibers [21]

\begin{tabular}{|c|c|}
\hline Parameters & Effect on fiber morphology \\
\hline \multicolumn{2}{|r|}{ Solution parameters } \\
\hline$\uparrow$ Molecular weight of polymer & $\begin{array}{l}\downarrow \text { Beads and droplet formation } \\
\text { Formation of irregular shape with larger pores }\end{array}$ \\
\hline$\uparrow$ Polymer concentration (viscosity) & $\begin{array}{l}\downarrow \text { Bead formation } \\
\uparrow \text { Fiber diameter (within optimal range) }\end{array}$ \\
\hline$\uparrow$ Solution conductivity & $\begin{array}{l}\downarrow \text { Uniform bead-free fibers } \\
\text { Fiber diameter with broad diameter distribution }\end{array}$ \\
\hline$\uparrow$ Solvent volatility & Generation of pores on the surface fiber (microtexture) \\
\hline \multicolumn{2}{|r|}{ Processing parameters } \\
\hline$\uparrow$ Applied voltage & $\uparrow \downarrow$ First fiber diameter, after that with bead formation \\
\hline $\begin{array}{l}\uparrow \text { Distance between tip and collector } \\
\text { (working distance) }\end{array}$ & $\begin{array}{l}\downarrow \text { Fiber diameter } \\
\text { Bead formation occurs in too short or too far distance } \\
\text { Minimum distance is required for uniform fibers generation }\end{array}$ \\
\hline$\downarrow$ Feed rate/flow rate & $\begin{array}{l}\downarrow \text { Fiber diameter } \\
\text { Bead formation with very high feed rate }\end{array}$ \\
\hline \multicolumn{2}{|r|}{ Ambient parameters } \\
\hline$\uparrow$ Temperature & $\downarrow \downarrow$ Fiber diameter and viscosity \\
\hline$\uparrow$ Humidity & Generation of circular pores on the fibers \\
\hline$\uparrow$ Air velocity & $\uparrow$ Fiber diameter \\
\hline
\end{tabular}




\section{FABRICATION OF NANOFIBERS}

There are many ways to fabricate nanofibers, such as melt spinning[8], air jet spinning [9] , template synthesis[10], drawing [11],electrospinning [9,12] (random, aligned, and core-shell nanofibers), self-assembly [13], centrifugal spinning [14], and phase separation [15]. Amongst these methods used to produce nanofibers, electrospinning is a simple and inexpensive one to produce a wide range of polymers in the form of nanoand micrometer-scale fibers [16]. This process involves using an electric field to convert polymer solution or melt into a fiber form [17]. Electrospun nanofibers with unique properties, i.e., large surface to volume ratio, high density of pores, and excellent surface adhesion, are used in many areas [18-20]. The electrospun nanofiber morphology is affected by the material being used and processing parameters [21] (Table 1).

\section{ELECTROSPINNING PROCESS}

\section{History}

First described the aerosols generated by the application of electric potential to the fluids in 1745. Further, Lord Rayleigh studied the amount of charge needed by the fluid to overcome the surface tension of a drop. Cooley and Morton patented the first device to spray the liquids under the influence of electrical charge in 1902 and 1903, and the fabrication of artificial silk was undertaken by Kiyohito et al. in 1929 [22]. In 1934, an original patent showed an initial technique of electrospinning including assemblies and methods and disclosed an experimental set up for the fabrication of polymer filaments using electrostatic force. Some of the historical events are: (i) in 1952, electrified droplets were produced by Vonnegut and Neubauer, (ii) in 1955, a series of liquids into aerosols under high electric potentials by Drozin; (iii) in 1966, ultra-thin fibers with different patterns under electrical spinning by Simons; and (iv) in 1971, acrylic fibers with diameters in the range of 0.051.1 microns under high DC voltage by Baumgarten. Until 1993, this technique had been known as electrostatic spinning and the term "electrospinning" was coined in 1994 [23]. After a half of the century, this technology attained renewed interest due to the development in nanotechnology. Moreover, the number of patents on the modification of the electrospinning processes increased remarkably since 1998 [24].

\section{APPLICATION OF NANOFIBERS}

It is remarkable that generated nanofibers have important characteristics such as large aspect ratio, high porosity, and the possibility to incorporate active components on a nanoscale [25-27] which can cover a wide range of industries such as semiconductors [28], protective materials (chemical resistant cosmetics and sound absorption) [29, 30], water purification [31], clean energy applications [32], enzyme immobilization [33],biosensor immunoassay [34]. The most promising applications lie in the biomedical field, which includes drug delivery carriers, tissue engineering, and wound dressing $[35,36]$. For tissue engineering approaches, the nanofiber scaffolds with seeded cells are incorporated [37]. For wound healing, the porous structure helps drug particles diffuse out of the matrix more efficiently. The drug release rate can be measured by controlling the thickness of the synthesized nanofibrous mat [38]. In the following sections of this review, aforesaid promising biomedical advances of electrospun nanofibers are discussed, and the research concept of each approach is addressed.

\section{Medical Application}

Most of human organs and tissues such as bone, skin, dentin, and collagen are present in a nanofibrous form. They are characterized by organized hierarchical fibrous structures that realign in nanometer scale, motivating and steering most of the nanofiber research towards biomedical and bioengineering applications [39]. Because they have unusual physical properties such as surface area, diameter, and porosity, which resemble similar characteristics to the extracellular matrix (ECM). Nanofibrous materials are also used in other biomedical applications such as medical implants, wound dressings, antimicrobial agents, drug delivery vehicles, biomimetic actuators, dental materials, enzyme immobilization scaffolds, and protective textiles for chemical and biological threats. For tissue engineering approaches, the nanofiber scaffolds with seeded cells are incorporated. For wound healing, the porous structure helps drug particles diffuse out of the matrix. The drug release rate can be measured by controlling the thickness of the synthesized nanofibrous mat. For drug delivery systems, the nanofibrous membranes were implemented with the drug component to deliver the targeted drug to the human body [40]. 


\section{TISSUE ENGINEERING}

Tissue engineering is an interdisciplinary field that involves knowledge in medicine, engineering, and biology to repair or replace lost or damaged tissues and organs through the use of cells, growth factors, injectable biopolymers, biomaterials and biomolecules. Thus, the goal of tissue engineering constructs on a nanometric scale is to make biocompatible scaffolds that exactly resemble the native ECM, provide direct interactions between cells and their micro-environment and allow spatiotemporal release of biological factors essential for tissue replacements [41]. Alharbi et al. used coaxial electrospinning to fabricate core-shell composite nanofibers with PLA in the core and PVA in the shell with significant enhancements in the surface wetting and mechanical properties. The metabolic activities of human embryonic kidney cells (HEK-293) and the attachment of the cells to the different nanofiber materials produced in this study were investigated. It is found that the coreshell PLA/PVA composite nanofiber scaffolds exhibited good cell growth behavior and increased ability for cell attachment [42]. Table 2 represents a summary of some of the most important biomedical applications of the nanofibers and Materials used to prepare nanofibers.

Blood vessel. Networks of blood vessels are critical for transport of oxygen and nutrients to all tissues, removal of metabolic waste products, and trafficking of stem and progenitor cells, which are critical for organ growth in the embryo and wound repair in the adult. Vascular reconstruction remains a major clinical challenge for patients requiring coronary artery and peripheral vascular bypass surgery. Due to insufficient autologous vessel replacements, tissue engineering vascular grafts (TEVGs), which combine a patient's cells with artificial vascular scaffolds to repair and replace damaged vessels, are considered to be one of the most promising candidates for clinical trials at present [43-45]. Jiang et al. by blending gelatin with PCL produced a composite Scaffold made from electrospun PCL/gelatin fibers. Apart from modulating surface wettability and mechanical properties, gelatin can also provide more binding sites for cells, thereby yielding increased cell numbers and larger spreading areas as compared to pure PCL scaffolds. It has been found that the introduction of gelatin not only altered the fiber diameter, but also dramatically changed the surface wettability from hydrophobic to hydrophilic. Although weak mixing and inhibited crystallinity resulted from high gelatin concentrations, which decreased scaffold mechanical properties, the PCL-C and P7G3-C groups were able to meet the required mechanical traits of human coronary arteries. Cytoskeleton staining and cell proliferation assays showed that mesenchymal stem cells had more favorable interactions with $\mathrm{PCL} /$ gelatin scaffolds as compared to PCL scaffolds, with P7G3-C hybrid scaffolds leading to potential applications in blood vessel tissue engineering [46]. Also, Pektok et al. discussed the preparation of PCL-based grafts with better endothelialization and healing properties in vivo than expanded polytetrafluoroethylene (e-PTFE). They showed that faster extracellular matrix formation was achieved with the decomposition of nanofibers grafts. So, these nanofibers with excellent healing properties can be applied to revascularization processes [47]. In another research poly(e-caprolactone) (PCL) and collagen nanofiber fabricated by Ju et al. Endothelial cells (EC) seeded on nanoscaled fibers showed enhanced cellular orientation and focal adhesion. Conversely, fabrication of a larger fiber diameter improved smooth muscle cells (SMC) infiltration into the scaffolds. To incorporate both of these properties into a scaffold, bilayered vascular scaffolds were produced. The inner layer yielded small diameter fibers and the outer layer provided large diameter fibers. They showed that the bilayered scaffolds permit $\mathrm{EC}$ adhesion on the lumen and SMC infiltration into the outer layer. Therefore, use of bilayered scaffolds may lead to improved vessel formation [48]. The main biological property of chitosan is blood coagulation. This is due to the free amino group in the specified conjugate. The cationic chitosan in the solution agglutinated the erythrocytes by electrostatic attraction, resulting in the formation of a cellular hemostatic plug that stopped bleeding [49]. The vertical graded chitosan/poly 3-caprolactone (CS/PCL) nanofibrous vessel scaffolds were fabricated with chitosan and PCL by sequential quantity grading co-electrospinning. According their result, the adhesion and proliferation of human umbilical vein endothelial cells (HUVEC) were enhanced on the gradient CS/PCL scaffold. Furthermore, HUVEC grew and formed an entire monolayer on the top side of the gradient CS/PCL scaffold. This scaffold could provide an approach to create small-diameter blood vessel grafts with innate properties of mammalian vessels of anticoagulation and rapid induction of re endothelialization [50]. In another study, a hydrophilic and compliant polyurethane namely Tecophilic (TP) blended with gelatin (gel) at a weight ratio of $70: 30[\mathrm{TP}(70) / \mathrm{gel}(30)]$ was electro- 
Table 2. Summary of the different materials for producing nanofibers and their biomedical applications

\begin{tabular}{|c|c|c|c|}
\hline Materials for nanofiber & Application & Result & Reference \\
\hline PCL/Gelatin nanofiber & $\begin{array}{l}\text { Vascular } \\
\text { tissue engi- } \\
\text { neering }\end{array}$ & $\begin{array}{l}\text { Introduction of gelatin not only altered the fiber diameter, } \\
\text { but also dramatically changed the surface wettability from } \\
\text { hydrophobic to hydrophilic and provide more binding sites } \\
\text { for cells, thereby yielding increased cell numbers and larger } \\
\text { spreading areas as compared to pure PCL scaffolds. }\end{array}$ & [46] \\
\hline $\begin{array}{l}\mathrm{PCL} / \text { polytetrafluoroethylene } \\
\text { (e-PTFE) scaffolds }\end{array}$ & $\begin{array}{l}\text { Vascular } \\
\text { tissue engi- } \\
\text { neering }\end{array}$ & $\begin{array}{l}\text { Faster extracellular matrix formation was achieved with the } \\
\text { decomposition of nanofibers grafts. }\end{array}$ & [47] \\
\hline PCL/collagen nanofiber & $\begin{array}{l}\text { Vascular } \\
\text { tissue engi- } \\
\text { neering }\end{array}$ & $\begin{array}{l}\text { Endothelial cells (EC) seeded on nanoscaled fibers showed } \\
\text { enhanced cellular orientation and focal adhesion. the bilay- } \\
\text { ered scaffolds permit EC adhesion on the lumen and SMC } \\
\text { infiltration into the outer layer. }\end{array}$ & [48] \\
\hline Chitosan/PCL nanofibrous & $\begin{array}{l}\text { Vascular } \\
\text { tissue engi- } \\
\text { neering }\end{array}$ & $\begin{array}{l}\text { the adhesion and proliferation of human umbilical vein } \\
\text { endothelial cells (HUVEC) were enhanced on the gradient } \\
\text { CS/PCL scaffold. Furthermore, HUVEC grew and formed } \\
\text { an entire monolayer on the top side of the gradient CS/PCL } \\
\text { scaffold. }\end{array}$ & [50] \\
\hline $\begin{array}{l}\text { Tecophilic (TP)/Gelatin nano- } \\
\text { fiber }\end{array}$ & $\begin{array}{l}\text { Vascular } \\
\text { tissue engi- } \\
\text { neering }\end{array}$ & $\begin{array}{l}\text { this nano-scaled fibrous scaffold mimicking the native } \\
\text { ECM, which could not only provide high mechanical } \\
\text { durability in terms of high burst strength and adequate } \\
\text { compliance comparable to those of native blood vessels to } \\
\text { withstand cyclic loading, but also present a blood compat- } \\
\text { ible surface to closely mimic the antithrombotic surface of } \\
\text { the native intima. }\end{array}$ & [51] \\
\hline $\begin{array}{l}\text { Hyaluronan (HA) / PCL (core- } \\
\text { shell) nanofiber }\end{array}$ & $\begin{array}{l}\text { Vascular } \\
\text { tissue engi- } \\
\text { neering }\end{array}$ & $\begin{array}{l}\text { Animal test indicated that the tubular graft made of aligned } \\
\text { HA/PLLA nanofibers could promote simultaneously regen- } \\
\text { eration of circumferentially oriented vSMCs with higher } \\
\text { contractility and luminal endothelium as well as capillary } \\
\text { formation. Obtained nanofibers showed anisotropic wetting } \\
\text { behaviour and compliable mechanical properties, well- } \\
\text { suited for vascular scaffolding }\end{array}$ & [52] \\
\hline $\begin{array}{l}\text { Silk fibroin /synthetic thermo- } \\
\text { plastic polyurethane (TPU) }\end{array}$ & $\begin{array}{l}\text { Vascular } \\
\text { tissue engi- } \\
\text { neering }\end{array}$ & $\begin{array}{l}\text { by blending these two materials, grafts with adequate } \\
\text { hydrophilicity can be fabricated, which is beneficial for } \\
\text { cell-matrix activity. On the TPU/fibroin hybrid graft, cell } \\
\text { populations were much higher than on the pure TPU graft, } \\
\text { which indicated that the addition of fibroin significantly } \\
\text { enhanced cell proliferation. }\end{array}$ & [53] \\
\hline $\begin{array}{l}\text { PCL/Ethyl Cellulose }(\mathrm{EC}) / \mathrm{Col}- \\
\text { lagen composite nanofiber }\end{array}$ & $\begin{array}{l}\text { Vascular } \\
\text { tissue engi- } \\
\text { neering }\end{array}$ & $\begin{array}{l}\text { Samples with } 10 \mathrm{wt} . \% \mathrm{PCL}, 1 \mathrm{wt} . \% \mathrm{EC} / 0.1 \mathrm{wt} \% \text { collagen } \\
\text { concentration was observed to be most promising amongst } \\
\text { others. Using this concentration, TBVGSs were manufac- } \\
\text { tured as a final product and the biomimetic blood vessels } \\
\text { were tailored to possess thin fiber diameters }\end{array}$ & [54] \\
\hline
\end{tabular}


Table 2. (Contd.).

\begin{tabular}{|c|c|c|c|}
\hline Materials for nanofiber & Application & Result & Reference \\
\hline $\begin{array}{l}\text { Gelatin/PCL/ chondroitin sulfate } \\
\text { (CS) composite nanofiber }\end{array}$ & $\begin{array}{l}\text { Vascular } \\
\text { tissue } \\
\text { engineering }\end{array}$ & $\begin{array}{l}\text { The introduction of CS in Gt/PCL nanofibers greatly } \\
\text { enhances their anticoagulant properties, prolongs their } \\
\text { coagulation time, and facilitates cell responses. Particularly, } \\
10 \% \mathrm{CS} / \mathrm{Gt} / \mathrm{PCL} \text { nanofibers display favorable cell } \\
\text { attachment, elongation, and proliferation. }\end{array}$ & {$[55]$} \\
\hline $\begin{array}{l}\text { Silk fibroin (SF) nanofibers and } \\
\text { homogeneous microspheres }\end{array}$ & $\begin{array}{l}\text { Vascular } \\
\text { tissue } \\
\text { engineering }\end{array}$ & $\begin{array}{l}\text { that cells cultured in 3D SF microsphere-nanofiber scaffolds } \\
\text { conferred the advantage of a matrix milieu that maintained } \\
\text { cell-cell and cell-biomaterial interactions, which might also } \\
\text { lead to the adherent cell networks and further transited to a } \\
\text { potential in vivo microenvironment }\end{array}$ & {$[56]$} \\
\hline $\begin{array}{l}\text { Chitosan/alginate nanofibers } \\
\text { encapsulated by hydroxyapatite } \\
\text { (HAp) and collagen }\end{array}$ & $\begin{array}{l}\text { Bone tissue } \\
\text { engineering }\end{array}$ & $\begin{array}{l}\text { The positive charge distribution on the surface was } \\
\text { hindered by using chitosan. The fabricated chitosan/ } \\
\text { alginate/collagen-Hap nanofibers improved cell spreading, } \\
\text { attachment, mineralization, and proliferation. }\end{array}$ & {$[59]$} \\
\hline $\begin{array}{l}\mathrm{Fe}_{3} \mathrm{O}_{4} / \text { poly-L-lactide) PLLA } \\
\text { (nanofibers }\end{array}$ & $\begin{array}{l}\text { Bone tissue } \\
\text { engineering }\end{array}$ & $\begin{array}{l}\text { Bony defects with a diameter of } 4 \mathrm{~mm} \text { were prepared in } \\
\text { rabbit tibias. } \\
\text { The histological results showed that the artificial bony } \\
\text { defects grafted with } \mathrm{Fe}_{3} \mathrm{O}_{4} / \mathrm{PLLA} \text { nanofibers exhibited a } \\
\text { visibly higher bone healing activity than those grafted with } \\
\text { neat PLLA }\end{array}$ & {$[60]$} \\
\hline $\begin{array}{l}\text { PLGA/gelatin biocomposite } \\
\text { scaffolds }\end{array}$ & $\begin{array}{l}\text { Bone tissue } \\
\text { engineering }\end{array}$ & $\begin{array}{l}\text { Blending PLGA with gelatin enhanced the hydrophilicity } \\
\text { but decreased the average fiber diameter and the mechanical } \\
\text { properties of the scaffolds under the same electrospinning } \\
\text { condition. The elongation of the osteoblast on the aligned } \\
\text { nanofibrous scaffold was parallel to the fiber arrangement } \\
\text { and the cell number was similar to that of randomly- } \\
\text { oriented scaffold. }\end{array}$ & {$[61]$} \\
\hline $\begin{array}{l}\text { Iron ions/nanoparticles within } \\
\text { cellulose acetate (CA) nanofibers }\end{array}$ & $\begin{array}{l}\text { Bone tissue } \\
\text { engineering }\end{array}$ & $\begin{array}{l}\text { The presence of iron acetate was revealed to highly contribute } \\
\text { to apatite particle formation, illustrating enhanced bioactive } \\
\text { behavior of the } \mathrm{CA} / \mathrm{Fe} \text { composite nanofibers, and suggesting } \\
\text { iron composite with CA can facilitate formation of apatite-like } \\
\text { mineral deposition on the mat surface. }\end{array}$ & {$[70]$} \\
\hline $\begin{array}{l}\text { Hydroxyapatite/gelatin-chitosan } \\
\text { core-shell nanofibers }\end{array}$ & $\begin{array}{l}\text { Bone tissue } \\
\text { engineering }\end{array}$ & $\begin{array}{l}\text { Due to the cationic nature of chitosan, the presence of } \\
\text { chitosan on the surface and gelatin in the interior highly } \\
\text { favored the cell attachment and proliferation. To further } \\
\text { enhance osteoblast cell proliferation, HAP was deposited } \\
\text { onto the surface of CS-PEO@GEL nanofibers by a wet } \\
\text { chemical method. From cultures of MG-63 cells, cells } \\
\text { viability was significantly promoted by HAP@CS-PEO@ } \\
\text { GEL nanofibers. }\end{array}$ & {$[71]$} \\
\hline PLA/CS nanofibers & $\begin{array}{l}\text { Skin tissue } \\
\text { engineering }\end{array}$ & $\begin{array}{l}\text { Degradation studies by accelerated ageing clearly demon- } \\
\text { strate the biodegradability of PLA-CS fibers. Fluorescent } \\
\text { imaging of HDF cells show the unidirectional cytoskeletal } \\
\text { arrangement on aligned PLA-CS fibers. Fiber orientation had } \\
\text { a great influence on the direction of cell spreading and hence } \\
\text { resulted in highly elongated cell morphology. }\end{array}$ & {$[77]$} \\
\hline
\end{tabular}


Table 2. (Contd.).

\begin{tabular}{|c|c|c|c|}
\hline Materials for nanofiber & Application & Result & Reference \\
\hline Silk fibroin (SF) nanofiber & $\begin{array}{l}\text { Skin tissue } \\
\text { engineering }\end{array}$ & $\begin{array}{l}\text { Electrospun silk fibroin (ESF) using Salt leaching } \\
\text { electrospining (SLE) showed highly interconnectivity } \\
\text { between pores, porosity, and water uptake abilities to } \\
\text { provide good condition for cell infiltration and proliferation. } \\
\text { Furthermore, that the ESF using SLE is related to increase } \\
\text { the infiltration of fibroblasts and the stratification of } \\
\text { keratinocytes. }\end{array}$ & [78] \\
\hline $\begin{array}{l}\text { Chitosan-poly (caprolactone) } \\
\text { (C/PCL) nanofiber }\end{array}$ & $\begin{array}{l}\text { Skin tissue } \\
\text { engineering }\end{array}$ & $\begin{array}{l}\text { Combine the important intrinsic biological properties of } \\
\text { chitosan and the mechanical integrity and stability of PCL, } \\
\text { evaluated as skin tissue engineering scaffolds using a mouse } \\
\text { cutaneous excisional skin defect model. C/PCL nanofiber } \\
\text { scaffolds increased the wound healing rate and promoted } \\
\text { more complete wound closure when compared with } \\
\text { Tegaderm, a commercially available occlusive dressing. }\end{array}$ & [79] \\
\hline $\begin{array}{l}\text { Core-shell structured PU } \\
\text { (polyurethane)/St (Starch) and } \\
\text { PU/St [Hyaluronic Acid (HA)] } \\
\text { nanofibers }\end{array}$ & $\begin{array}{l}\text { Skin tissue } \\
\text { engineering }\end{array}$ & $\begin{array}{l}\text { The core-shell PU/St and PU/St (HA) nanofibers were } \\
\text { evaluated in vitro by using mouse fibroblasts (L929) } \\
\text { cells. as scaffolds were biocompatible and nontoxic. Cell } \\
\text { morphology and viability results were exhibited significant } \\
\text { enhancement in cell promoting and cell attachment. HA } \\
\text { modification of nanofibers significantly was promoted cell } \\
\text { adhesion into nanofibrous scaffolds. }\end{array}$ & [81] \\
\hline $\begin{array}{l}\text { Soy protein isolate/silk fibroin } \\
\text { (SPI/SF) nanofibrous }\end{array}$ & $\begin{array}{l}\text { Skin tissue } \\
\text { engineering }\end{array}$ & $\begin{array}{l}\text { That Ethanol vapor treatment to the nanofibers provides } \\
\text { enhanced stability to the scaffold but at the cost of } \\
\text { transparency. fabricated nanofibrous scaffolds were } \\
\text { non-toxic towards normal mammalian cells. In addition, } \\
\text { healing of full-thickness wound in rats within } 14 \text { days after } \\
\text { treatment with a nanofibrous scaffold. }\end{array}$ & [82] \\
\hline Gelatin Nano fibrous & $\begin{array}{l}\text { Cartilage } \\
\text { tissue } \\
\text { engineering }\end{array}$ & $\begin{array}{l}\text { Their results demonstrate that the properties of } \\
\text { Nano fibrous scaffolds which were cross-linked with } \\
\text { glyceraldehyde have acceptable water stability, mechanical, } \\
\text { cytotoxicity and cell adherence properties. }\end{array}$ & [87] \\
\hline Gelatin/PLA nanofibers & $\begin{array}{l}\text { Cartilage } \\
\text { tissue } \\
\text { engineering }\end{array}$ & $\begin{array}{l}\text { To further improve the repairing effect of cartilage, a } \\
\text { modified scaffold (3DS-2) cross-linked with hyaluronic } \\
\text { acid (HA) was also fabricated. 3DS-1 possessed porous } \\
\text { and nanofibrous structure, which could mimic the } \\
\text { structure of natural ECM and it presented superabsorbent } \\
\text { property and could improve the growth of chondrocytes } \\
\text { in vitro. Compared with 3DS-1, 3DS-2 exhibited similar } \\
\text { structure and water absorption property but higher } \\
\text { compressive strength. Moreover, they proved that 3DS-2 } \\
\text { could significantly repair the cartilage defect in rabbits. }\end{array}$ & [89] \\
\hline
\end{tabular}


Table 2. (Contd.)

\begin{tabular}{|c|c|c|c|}
\hline Materials for nanofiber & Application & Result & Reference \\
\hline $\begin{array}{l}\text { Poly } \varepsilon \text {-caprolactone }(\mathrm{PCL}) / \\
\text { gelatin with } 1 \text { wt. } \% \text { of multi- } \\
\text { walled carbon nanotubes } \\
\text { (MWNTs) }\end{array}$ & $\begin{array}{l}\text { Cartilage } \\
\text { tissue } \\
\text { engineering }\end{array}$ & $\begin{array}{l}\text { The presence of MWNTs led to an increase in the } \\
\text { hydrophilicity and tensile strength, while maintaining an } \\
\text { appropriate level of porosity percentage. The bioactivity } \\
\text { and biodegradation evaluation demonstrated that the } \\
\text { scaffolds containing MWNTs presented more bioactivity } \\
\text { and slower degradation rate. Cell culture study showed that } \\
\text { the nanocomposite scaffolds did not have any cytotoxicity. }\end{array}$ & [89] \\
\hline $\begin{array}{l}\text { Chondroitin sulfate and gelatin } \\
\text { (GEL-CS) incorporated by } \\
\text { polycaprolactone (PCL) } \\
\text { nanofiber }\end{array}$ & $\begin{array}{l}\text { Cartilage } \\
\text { tissue } \\
\text { engineering }\end{array}$ & $\begin{array}{l}\text { The MTT anSSEM results illustrated supported cellular } \\
\text { attachment and viability of hMSCs on scaffolds. Sulfated } \\
\text { glycosaminoglycan secretion staining, genes expression } \\
\text { of COL2a1 and SOX9 and also type II collagen protein } \\
\text { approved the differentiation of seeded hMSCs to } \\
\text { chondrocytes without using any external chondrogenic } \\
\text { differential factor. The scaffolds containing the highest } \\
\text { GEL-CS content }(2 / 1) \text { exhibit better chondrogenesis } \\
\text { differentiation results }\end{array}$ & [90] \\
\hline $\begin{array}{l}\text { Coaxial poly(glycerol sebacate) } \\
\text { (PGS)/poly(caprolactone) (PCL) } \\
\text { aligned nanofibers }\end{array}$ & $\begin{array}{l}\text { Cartilage } \\
\text { tissue } \\
\text { engineering }\end{array}$ & $\begin{array}{l}\text { The coaxial PGS/PCL aligned nanofibers were able } \\
\text { to promote a much more sustained release of KGN } \\
\text { in comparison to monoaxial PCL aligned scaffolds. } \\
\text { Importantly, KGN-loaded aligned nanofiber scaffolds } \\
\text { promoted significantly the proliferation and chondrogenic } \\
\text { differentiation of hBMSC, favoring cartilage-like ECM } \\
\text { production and gene expression, in the absence of } \\
\text { chondrogenic cytokine TGF- } \beta 3\end{array}$ & [91] \\
\hline $\begin{array}{l}\text { Polyvinyl alcohol (PVA)/chito- } \\
\text { san nanofibrous }\end{array}$ & $\begin{array}{l}\text { Nerve tis- } \\
\text { sue engi- } \\
\text { neering }\end{array}$ & $\begin{array}{l}\text { Addition of chitosan to the PVA scaffolds enhances vi- } \\
\text { ability and proliferation of nerve cells, which increases the } \\
\text { biocompatibility of the scaffolds. }\end{array}$ & [97] \\
\hline $\begin{array}{l}\text { Poly(L-lactic acid-co-3-caprolac- } \\
\text { tone)/silk fibroin (PS) /polyani- } \\
\text { line (PANi) nanofibers }\end{array}$ & $\begin{array}{l}\text { Nerve tis- } \\
\text { sue engi- } \\
\text { neering }\end{array}$ & $\begin{array}{l}\text { The results of the viability and morphology of mouse } \\
\text { Schwann cells on the nanofibrous meshes showed that PS- } \\
\text { PANi-1 loaded with NGF exhibited the highest cell number } \\
\text { after } 5 \text { days culture and the aligned nanofibers could guide } \\
\text { cell orientation. The scaffolds loaded with NGF under elec- } \\
\text { trical stimulation could effectively support PC12 neurite } \\
\text { outgrowth and increase the percentage of neurite-bearing } \\
\text { cells as well as the median neurite length }\end{array}$ & [98] \\
\hline $\begin{array}{l}\text { Keratose (oxidative keratin, } \\
\text { KOS) nanoparticles-coating PVA } \\
\text { nanofibers (KNPs/PVA) }\end{array}$ & $\begin{array}{l}\text { Nerve tis- } \\
\text { sue engi- } \\
\text { neering }\end{array}$ & $\begin{array}{l}\text { KNPs/PVA nanofibers displayed better cyto-biocompatibil- } \\
\text { ity in terms of cell morphology, adhesion and proliferation } \\
\text { compared with PVA nanofibers and KOS/PVA blend nanofi- } \\
\text { bers. These results demonstrated that polymeric nanofibers } \\
\text { surface modified with oxidative keratin nanoparticles have } \\
\text { superior biocompatibility and mechanical properties. }\end{array}$ & {$[100]$} \\
\hline
\end{tabular}


Table 2. (Contd.).

\begin{tabular}{|c|c|c|c|}
\hline Materials for nanofiber & Application & Result & Reference \\
\hline PLLA/gelatin scaffold & $\begin{array}{l}\text { Nerve tissue } \\
\text { engineering }\end{array}$ & $\begin{array}{l}\text { Nerve guidance scaffold (NGS) is similar to the native } \\
\text { nerve adventitia in structure and mechanical properties. } \\
\text { In the study on the treatment of sciatic nerve injury in } 24 \\
\text { weeks in vivo, the biomimetic PLLA/gelatin nanofiber } \\
\text { NGS can promote Schwann cells' proliferation and migra- } \\
\text { tion and direct the rapid regeneration of nerve fibers, and } \\
\text { enhance nerve function recovery. }\end{array}$ & {$[101]$} \\
\hline $\begin{array}{l}\text { PCL/gelatin/graphene oxide } \\
\text { nanofibers }\end{array}$ & $\begin{array}{l}\text { Nerve tissue } \\
\text { engineering }\end{array}$ & $\begin{array}{l}\text { This structure showed slightly higher level of biodegrada- } \\
\text { tion in comparison to PCL/gelatin nanofibers, as nanofibers } \\
\text { nature is turned to more hydrophilic as a result of graphene } \\
\text { incorporation however, the scaffold has still retained its } \\
\text { structural integrity. Cell culture studies showed that PCL/ } \\
\text { gelatin/ graphene nanofibrous mats provide a suitable mi- } \\
\text { croenvironment for cell migration, adhesion and prolifera- } \\
\text { tion. Furthermore, no cytotoxicity was detected in presence } \\
\text { of graphene }\end{array}$ & {$[102]$} \\
\hline $\begin{array}{l}\text { Chitosan-based electrospun } \\
\text { nanofibers }\end{array}$ & $\begin{array}{l}\text { Wound } \\
\text { dressings }\end{array}$ & $\begin{array}{l}\text { The prepared wound dressings were tested for IIIa and IIIb } \\
\text { degree burns. These nanofiber dressings exhibited adequate } \\
\text { wound ventilation, exudate absorption, and protection from } \\
\text { infections }\end{array}$ & {$[106]$} \\
\hline PCL/GT/Cur nanofibers & $\begin{array}{l}\text { Wound } \\
\text { dressings }\end{array}$ & $\begin{array}{l}\text { The antibacterial experiments indicated PCL/GT/Cur } \\
\text { nanofibers had antibacterial ability of } 99.9 \% \text { against } \\
\text { methicillin-resistant Staphylococcus aureus (MRSA) and } \\
85.14 \% \text { against extended spectrum beta lactamase (ESBL). } \\
\text { microscopic studies demonstrated that PCL/GT/Cur scaf- } \\
\text { folds increased the collagen content in treating diabetic } \\
\text { wounds and promoted healing process, indicating the great } \\
\text { potential of this scaffold applied for healing of wounds in } \\
\text { the rat models }\end{array}$ & {$[103]$} \\
\hline $\begin{array}{l}\text { Polycaprolactone/chitosan/aloe } \\
\text { vera (PCL/CS/AV) nanofiber }\end{array}$ & $\begin{array}{l}\text { Wound } \\
\text { dressings }\end{array}$ & $\begin{array}{l}\text { The inhibition rates of PCL/CS and PCL/CS/AV NFMs } \\
\text { against E. coli were } 92.92 \% \text { and } 96.68 \% \text {, respectively. The } \\
\text { addition of AV in the NFMs can increase the antibacterial } \\
\text { effect of the NFMs on E. coli. This might be due to the } \\
\text { presence of substances such as acemannan, anthroquinones } \\
\text { and salicylic acid in AV. The proliferation of ECs on the } \\
\text { PCL/CS/AV NFM exhibited good biocompatibility in } 5 \\
\text { days, which indicated the PCL/CS/AV NFM was suitable } \\
\text { for short-term dressing or acute wounds ( } 1-4 \text { days). }\end{array}$ & {$[114]$} \\
\hline $\mathrm{Cu} /$ cellulose $(\mathrm{CE})$ nanofibrous & $\begin{array}{l}\text { Wound } \\
\text { dressings }\end{array}$ & $\begin{array}{l}\mathrm{Cu} / \mathrm{CE} \text { nanofibers showed faster release }(80 \%) \text { of copper } \\
\text { ions to aqueous environment within } 24 \mathrm{~h} \text { and seemed to } \\
\text { advance towards plateau for the next five days. Also, this } \\
\text { nanofiber exhibited excellent antibacterial efficacy against } \\
\text { both gram-negative Escherichia coli (E. coli) and gram-pos- } \\
\text { itive Staphylococcus aureus (S. aureus) bacteria. NIH3T3 } \\
\text { fibroblast cells have excellent migrating and proliferat- } \\
\text { ing ability on prepared nanofibrous mats. The presence of } \\
\text { bound alkali lignin on the surface of nanofibers added a } \\
\text { benefit of antioxidant activity. }\end{array}$ & {$[115]$} \\
\hline
\end{tabular}


Table 2. (Contd.).

\begin{tabular}{|c|c|c|c|}
\hline Materials for nanofiber & Application & Result & Reference \\
\hline $\begin{array}{l}\text { Polyvinylidene fluoride } \\
\text { (PVDF)/titanium nanotubes } \\
\text { (TNT) nanofibers }\end{array}$ & Facemask & $\begin{array}{l}\text { Antibacterial and zone of inhibition studies revealed that } \\
\text { the prepared filter media was highly efficient against both } \\
\text { Escherichia coli and Staphylococcus aureus. In this study, } \\
\text { it was found that } 15 \mathrm{wt} \% \text { of the filler proved for the highest } \\
\text { bacterial filter efficiency of } 99.88 \%\end{array}$ & [116] \\
\hline $\mathrm{PAN} / \mathrm{CuO}$ nanofibers & Facemask & $\begin{array}{l}\text { Antimicrobial test results (using disk diffusion method) } \\
\text { proved that inhibition zone was gradually increased with } \\
\text { increasing concentration of CuO in PAN nanofibers. It can } \\
\text { be also observed that copper oxide was effective for both } \\
\text { types (gram positive and gram negative) of bacteria which } \\
\text { represented excellent antimicrobial feature of copper oxide. } \\
\text { Excellent antibacterial efficacy was observed for samples } \\
\text { with } 1.00 \% \mathrm{CuO} \text { concentration. }\end{array}$ & [120] \\
\hline $\begin{array}{l}\text { Poly Vinylidene Fluoride } \\
\text { nanofibers blended with silver } \\
\text { nanoparticles }\left(\mathrm{AgNO}_{3}\right)\end{array}$ & Facemask & $\begin{array}{l}\text { Polypropylene non-woven substrate was used as base mate- } \\
\text { rial for collecting the nanofibres. Zone of inhibition test } \\
\text { showed that pure PVDF has minimum amount of antibacte- } \\
\text { rial activity due to its inbuilt electrostatic property on both } \\
\text { gram positive and gram-negative bacteria. Addition of vary- } \\
\text { ing silver concentrations the antibacterial activity increased } \\
\text { several orders against microorganisms and } 15 \mathrm{wt} \% \text { of silver } \\
\text { showed maximum antibacterial activity. This research } \\
\text { shows the bacterial filtration efficiency for the prepared } \\
\text { PVDF-Ag nanofibres as } 99.86 \%\end{array}$ & [121] \\
\hline
\end{tabular}

spun. They proved that this nano-scaled fibrous scaffold mimicking the native ECM, which could not only provide high mechanical durability in terms of high burst strength and adequate compliance comparable to those of native blood vessels to withstand cyclic loading, but also present a blood compatible surface to closely mimic the antithrombotic surface of the native intima [51]. Yuan et al. prepared highly aligned hyaluronan/ poly-L-lactic acid (HA/PLLA) nanofibers in core-shell structure. Animal test indicated that the tubular graft made of aligned HA/PLLA nanofibers could promote simultaneously regeneration of circumferentially oriented vSMCs with higher contractility and luminal endothelium as well as capillary formation. Obtained nanofibers showed anisotropic wetting behaviour and compliable mechanical properties, well-suited for vascular scaffolding [52]. Also, Small-diameter vascular grafts made of natural silk fibroin and synthetic thermoplastic polyurethane (TPU) were produced by Yu et al. Their result showed that by blending these two materials, grafts with adequate hydrophilicity can be fabricated, which is beneficial for cell-matrix activity. On the TPU/fibroin hybrid graft, cell populations were much higher than on the pure TPU graft, which indicated that the addition of fibroin significantly enhanced cell proliferation [53]. Aydogdu et al. in another study produced PCL/Ethyl Cellulose (EC)/Collagen electrospun scaffold. Samples with 10 wt \% PCL, 1 wt \% EC/0.1 wt \% collagen concentration was observed to be most promising amongst others. Using this concentration, TBVGSs were manufactured as a final product and the biomimetic blood vessels were tailored to possess thin fiber diameters [54]. Biomimetic gelatin (Gt)/polycaprolactone (PCL) composite nanofibers incorporating a different amount of chondroitin sulfate (CS) were developed via electrospinning technology by Kong et al. The introduction of CS in Gt/PCL nanofibers greatly enhances their anticoagulant properties, prolongs their coagulation time, and facilitates cell responses. Particularly, $10 \% \mathrm{CS} / \mathrm{Gt} / \mathrm{PCL}$ nanofibers display favorable cell attachment, elongation, and proliferation which could be developed as a promising tissue-engineering scaffold in blood vessel repair and regeneration [55]. Also, in another research, 


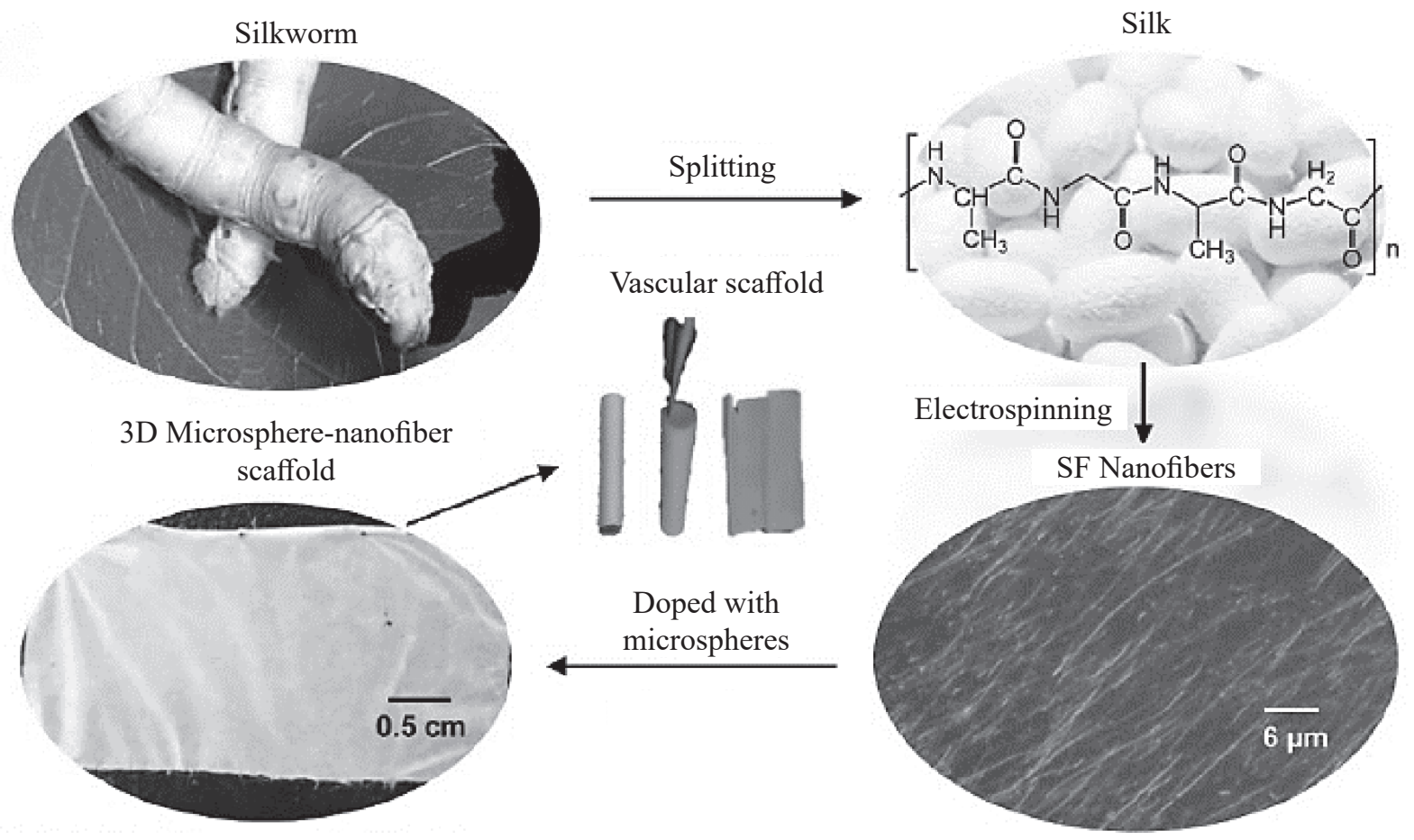

Fig. 2. Preparation and images of SF nanofiber, 3D microsphere-nanofiber scaffolds and tubular scaffolds [56].

Liu et al. developed 3D scaffolds consisting of silk fibroin (SF) nanofibers and homogeneous microspheres by electrospinning and microfluidics. The morphologies were smooth, they could be rolled into tubular scaffolds (Fig. 2) Their results demonstrated that cells cultured in 3D SF microsphere-nanofiber scaffolds conferred the advantage of a matrix milieu that maintained cell-cell and cell-biomaterial interactions, which might also lead to the adherent cell networks and further transited to a potential in vivo microenvironment [56].

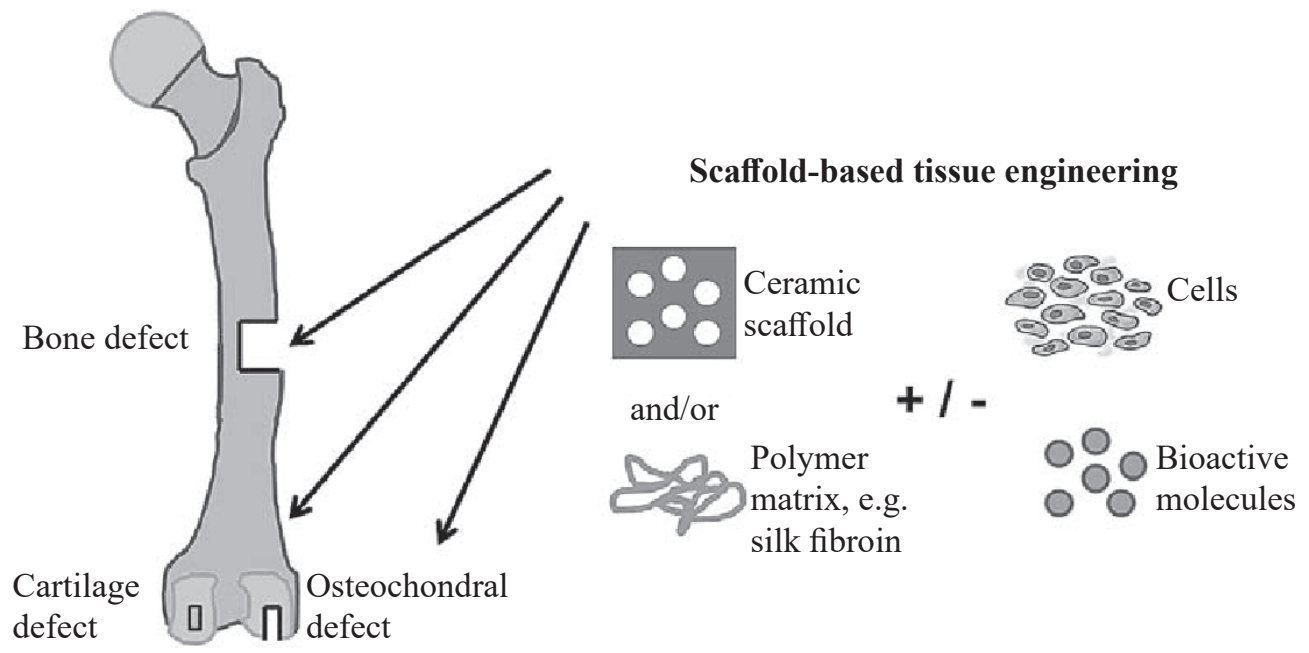

Fig. 3. Bone scaffold: the bone capacity or the osteogenic potential of a bone graft is given by cells involved in bone formation, such as mesenchymal stem cells, osteoblasts, and osteocytes. The term osteoconductive refers to the scaffold or matrix which stimulates bone cells to grow on its surface [58]. 
Bone. Bone defects are a difficult orthopedic problem and much research has focused on their treatment [57]. Bone regeneration is a surgical technique (Fig. 3) that uses barrier membranes to direct, or guide, the growth of new bone at the site of the defect. The principle is that the barrier membranes create and maintain a space above the bone defect; this allows the slower mesenchymal cells with osteogenic potential to populate the defect and regenerate without interference from the more quickly proliferating overlying soft tissues. Protection of the clot in the defect, exclusion of gingival connective tissue cells, and preparation of an enclosed space in which osteogenic cells can migrate from the bone are three essential elements of a successful outcome. Many types of grafts have been used as space maintainers between the membrane and the bone defect. Autografts, allografts, and xenografts have all been used successfully, either alone or in combination, for bone regeneration using particulate materials [58].

$\mathrm{Yu}$ et al. synthesized chitosan/alginate nanofibers encapsulated by hydroxyapatite (HAp) and collagen to decrease the collagen solubility at the implanted place. The core-shell morphology with a large surface area was attained using electrospinning process. The positive charge distribution on the surface was hindered by using chitosan. The collagen decomposition over a long period of time was measured by the coating using HAp and collagen. The fabricated chitosan/alginate/collagen-Hap nanofibers improved cell spreading, attachment, mineralization, and proliferation. This approach was used to stabilize collagen bioactivity over long period of time for different bone tissue engineering applications [59]. In another study, Lai et al. fabricated $\mathrm{Fe}_{3} \mathrm{O}_{4} /$ poly-L-lactide) PLLA(nanofibers using an electrospinning method. Bony defects with a diameter of $4 \mathrm{~mm}$ were prepared in rabbit tibias. $\mathrm{Fe}_{3} \mathrm{O}_{4} /$ PLLA nanofibers were grafted into the drilled defects and histological examination and computed tomography (CT) image detection were performed after an eight-week healing period. The histological results showed that the artificial bony defects grafted with $\mathrm{Fe}_{3} \mathrm{O}_{4} /$ PLLA nanofibers exhibited a visibly higher bone healing activity than those grafted with neat PLLA [60]. PLGA and PLGA/gelatin biocomposite scaffolds produced by Meng et al. Blending PLGA with gelatin enhanced the hydrophilicity but decreased the average fiber diameter and the mechanical properties of the scaffolds under the same electrospinning condition. The cell culture results showed that the elongation of the osteoblast on the aligned nanofibrous scaffold was parallel to the fiber arrangement and the cell number was similar to that of randomly-oriented scaffold, indicating that the aligned nanofibrous scaffold provide a beneficial approach for the bone regeneration [61]. In another research, Wan et al. fabricated three-dimensional carbon nanofibers via carbonization of bacterial cellulose (BC) naofibers. Surface treatment of CNFs in nitric acid increased HAp nucleation and growth and changed the morphology of the resultant HAp crystals. HAp crystals formed on the as-prepared CNFs were needle-like while the surface of HNO3- treated CNFs had some rod-like HAps. The results of their study could be of significance in the fields of carbonaceous materials and biomaterials for bone tissue engineering [62]. Frohbergh et al. generate electrospun and HA-containing fibrous chitosan scaffolds that was cross-linked with genipin. Crosslinking with genipin resulted in five-fold increase in the Young's modulus approximating those of periosteum. This scaffold was potential candidates for non-weight bearing bone tissue engineering [63]. In Liu et al.'s study, blends of aniline pentamer-graft-gelatin (AP-gGA) and poly(L-lactide) (PLLA) were electrospun to prepare uniform nanofibers as biomimetic scaffolds. The nanofibers exhibited good electroactivity, thermal stability and biodegradability. The biocompatibility of the nanofibers in vitro was evaluated by the adhesion and proliferation of mouse preosteoblastic MC3T3-E1 cells. The cellular elongation was significantly greater on electroactive AP-g-GA/PLLA nanofibers than on PLLA nanofibers. Their results demonstrated that the biodegradable and electroactive AP-g-GA/PLLA nanofibers had potential application in vivo as bone repair scaffold materials in tissue engineering [64]. Li et al. prepared nanofibers composed of mesoporous silica nanoparticles/chitosan (MSN/CTS) by electrospinning. The surface of the MSN/CTS nanofibers became rougher with the increase in MSN content. The MSN/CTS nanofibrous scaffolds supported osteoblast attachment, proliferation and bone formation, in addition to Alkaline phosphatase (ALP) expression and mineral deposition [65]. Also, Shao et al. fabricated a scaffold consisting of multilayer nanofiber fabrics (MLNFFs) by weaving nanofiber yarns of polylactic acid (PLA) and Tussah silk fibroin (TSF) by electrospinning. Woven scaffolds supported adhesion and proliferation of mousemesenchymal stem cells, and promoted biomineralization via alkaline phosphatase and mineral deposition. The scaffolds significantly enhanced the formation of new bone 
in damaged femoral condyle in rabbits [66]. Ao et al. electrospun cellulose/nano-HA nanocomposite nanofibers $(\mathrm{ECHNN})$ in another study. In vitro cell culture with human dental follicle cells (HDFCs) demonstrated that the incorporation of nano-HA did not bring cytotoxicity to the cellulose scaffolds and could promote cell proliferation. The embodiment of novel nanofibrous structure analogue to nature ECM, high strength as well as excellent biocompatibility would allow the ECHNN a promising candidate for future bone tissue engineering applications [67]. Ghorbani et al. in another investigation, coated electrospun polyurethane graphene oxide scaffold with polydopamine (PDA) by immersing the constructs in dopamine hydrochloride solution under the alkaline condition for $24 \mathrm{~h}$. They investigated the synergic effects of graphene oxide (GO) and PDA on the osteogenic expression. Although the GO incorporated into the electrospun scaffolds ameliorates the physical and biological properties, the polyurethane (PU)-GO-PDA scaffold showed significantly improved properties, such as wettability, water absorption, and both cell attachment and proliferation. The biological evaluations showed that the PU-GO-PDA scaffold highly increased proliferation compared to the control and the PU-GO groups. PU-GO-PDA scaffold also led to a significant increase in the A differentiation property. Their result demonstrated that the PU-GO-PDA scaffold is an appropriate substrate for in vivo studies and the bone regeneration of tissues [68]. Wang et al. fabricated a scaffold from HA and TCP (60/40, wt $\%)$ filled with phage nanofibers displaying a high-density Arg-Gly-Asp (RGD) peptide, which induced osteogenesis and angiogenesis. The RGD peptide in the extracellular matrix regulated the migration and adhesion of the endothelial cells [69]. In another study, a nanocomposite mats by electrospinning from cellulose acetate and traces from iron produced by Mousa et al. . Their results proved that the presence of iron acetate was revealed to highly contribute to apatite particle formation, illustrating enhanced bioactive behavior of the $\mathrm{CA} / \mathrm{Fe}$ composite nanofibers, and suggesting iron composite with CA can facilitate formation of apatite-like mineral deposition on the mat surface. Furthermore, in vitro cell culture seeded with hFOB cells have no cytotoxicity effect and could enhance and promote osteoblast cell attachment and proliferation among mats' porous structure. This nanostructure is close to natural ECM with excellent biocompatibility [70]. Chen et al. Prepared biomimetic hydroxyapatite/ gelatin-chitosan core-shell nanofibers composite scaf- folds by coaxial electrospinning technique. Due to the cationic nature of chitosan, the presence of chitosan on the surface and gelatin in the interior highly favored the cell attachment and proliferation. To further enhance osteoblast cell proliferation, HAP was deposited onto the surface of CS-PEO@GEL nanofibers by a wet chemical method. From cultures of MG-63 cells, cells viability was significantly promoted by HAP@CS-PEO@GEL nanofibers. Those results indicated that biomimetic composite scaffold ofHAP@CS-PEO@GEL nanofibers have better biocompatibility and could be suggested as a promising material to promote osteoblast cell growth in bone tissue engineering [71].

Skin. Skin is the barrier between the internal and external environment and is the largest organ of the human body. Skin consists of three layers: epidermis, dermis, and hypodermis (subcutaneous layer). Due to the presence of stem cells, the wounded epidermis can stimulate self-regeneration. Yet, in case of deep injuries and burns, the process of healing is not adequate, thus leading to a chronic wound. Any loss of full-thickness skin more than $4 \mathrm{~cm}$ diameter needs grafting for its treatment [72]. In dermal tissue, an extracellular matrix (ECM) is a collection of extracellular molecules secreted by cells that provide spatial and mechanical signals to cells and physical support to tissues. ECM is composed mainly of collagen, elastin, and reticular fibers. Thus, it is mandatory to design skin substitutes that can mimic the dermal ECM of damaged tissue or organ to sequentially regenerate [73].

Pezeshki-Modaress et al. fabricated gelatin/GAG (glycosaminoglycan) nanofibrous mats using electrospinning process. Trifluoroethanol (TFE)/water solvent system results in good solubility and electrospin ability at the same time. The best ratio of water at solvent system for having reasonable solubility was $50 \%(\mathrm{v} / \mathrm{v})$. Their result showed that the increase in applied voltage or flow rate leads to the increase in the SDF(standard deviation of fiber diameter) and the impact of flowrate on SDF is influenced by blend ratios. Process conditions and gelatin/GAGblend ratio could be chosen according to the model in this study. The best condition for having least MFD (mean fiber diameter) and narrower distribution is achieved for electrospinning of gelatin/GAG $15 \%$ at $18.7 \mathrm{kV}$ and $0.6 \mathrm{~mL} / \mathrm{h}$ flow rate. The electrospun gelatin/GAG nanofibrousmats have a potential for using as scaffold for skin, cartilage and cornea tissue engineering [74]. In another study, 
Lin et al. engineered extra cross-linking to electrospun chitosan nanofibers using a natural polymer-pectin. The novel pectin cross-linked chitosan electrospun scaffold was stronger and less likely to break than a plain chitosan electrospun scaffold. Also, the pectinchitosan scaffold was able to maintain its fibrous morphology in the saline solution for over two weeks, providing a substrate with nanoroughness for fibroblast growth during wound healing. According their result, with a fiber size like that of collagen fibrils in ECM, the pectin-chitosan scaffold was able to promote fast cell proliferation and type I collagen secretion which can promote tissue regeneration. Compared to plain chitosan scaffolds, the pectin-chitosan scaffolds could absorb liquid, or exudate, from their surroundings more quickly and maintained a small volume change. With a slightly slower cell growth, the pectin-chitosan scaffold offered much higher tensile properties that were much closer to those of natural skin [75]. Asran et al. prepared nanofibers by electrospinning from pure polyvinyl alcohol (PVA), polyhydroxybutyrate (PHB), and their blends. The hydrolytic degradation of PHB was accelerated with increasing PVA fraction. Cell culture experiments with a human keratinocyte cell line (HaCaT) and dermal fibroblast on the electrospun PHB and PVA/PHB blend nanofibers showed maximum adhesion and proliferation on pure PHB. However, the addition of 5 wt \% PVA to PHB inhibited growth of $\mathrm{HaCaT}$ cells but not of fibroblasts. On the contrary, adhesion and proliferation of $\mathrm{HaCaT}$ cells were promoted on PVA/PHB (50/50) fibers, which inhibited growth of fibroblasts [76]. Homogenously distributed aligned PLACS nanofibers were fabricated using formic acid/ acetone/chloroform solvent system on a parallel blade target. Degradation studies by accelerated ageing clearly demonstrate the biodegradability of PLA-CS fibers. Fluorescent imaging of HDF cells show the unidirectional cytoskeletal arrangement on aligned PLACS fibers. Fiber orientation had a great influence on the direction of cell spreading and hence resulted in highly elongated cell morphology. Shalumon et al.'s studies indicate that the prepared PLA-CS aligned nanofibers are promising material for skin tissue engineering [77]. Also, Park et al. produced silk fibroin (SF) nanofiber using electrospinning with the addition of $\mathrm{NaCl}$ crystals to nanofiber to artificially create larger pores than conventional electrospinning. Their electrospun silk fibroin (ESF) using Salt leaching electrospining (SLE) showed highly interconnectivity between pores, poros- ity, and water uptake abilities to provide good condition for cell infiltration and proliferation. Furthermore, that the ESF using SLE is related to increase the infiltration of fibroblasts and the stratification of keratinocytes [78]. In the research that performed by Levengood et al., Electrospun chitosan-poly(caprolactone) (CPCL) nanofiber scaffolds, which combine the important intrinsic biological properties of chitosan and the mechanical integrity and stability of PCL, evaluated as skin tissue engineering scaffolds using a mouse cutaneous excisional skin defect model. CPCL nanofiber scaffolds increased the wound healing rate and promoted more complete wound closure when compared with Tegaderm, a commercially available occlusive dressing. The architecture of the scaffold was biomimetic for the native extra cellular matrix in terms of fiber morphology and dimensionality and likely serves as an immediate provisional matrix for keratinocyte and fibroblast migration in support of wound closure [79]. Collagen/PCL nanofibers containing hydrophilic gentamicin drug (an antibiotic drug) were fabricated by Abdul Khodir et al. The encapsulation of drugs, such as gentamicin sulfate, also improves the bioactivity of nanofibers, due to the efficient loading and a controlled drug release towards the site of interest. Their experimental studies have demonstrated that collagen added fibers can be efficaciously used to administrate gentamicin for $72 \mathrm{~h}$ without any toxic in vitro response, thus emerging as a valid candidate for the therapeutic treatment of infected wounds [80]. Also, in another investigation that performed by Movahedi et al. coreshell structured PU (polyurethane)/St (Starch) and PU/ St (Hyaluronic Acid (HA)) nanofibers were fabricated with coaxial electrospinning technique. The core-shell $\mathrm{PU} / \mathrm{St}$ and PU/St (HA) nanofibers were evaluated in vitro by using mouse fibroblasts (L929) cells. According their result, in vitro cytotoxicity against L929 cells culture were illustrated the nanofibers as scaffolds were biocompatible and nontoxic. Cell morphology and viability results were exhibited significant enhancement in cell promoting and cell attachment. HA modification of nanofibers significantly was promoted cell adhesion into nanofibrous scaffolds. It seems that the PU/St (HA) core-shell nanofibers can be a novel scaffold forwound healing and skin tissue engineering [81]. Recently, Biocompatible soy protein isolate/silk fibroin (SPI/SF) nanofibrous scaffolds were successfully fabricated through electrospinning by Varshney et al. . Their results demonstrated that Ethanol vapor 


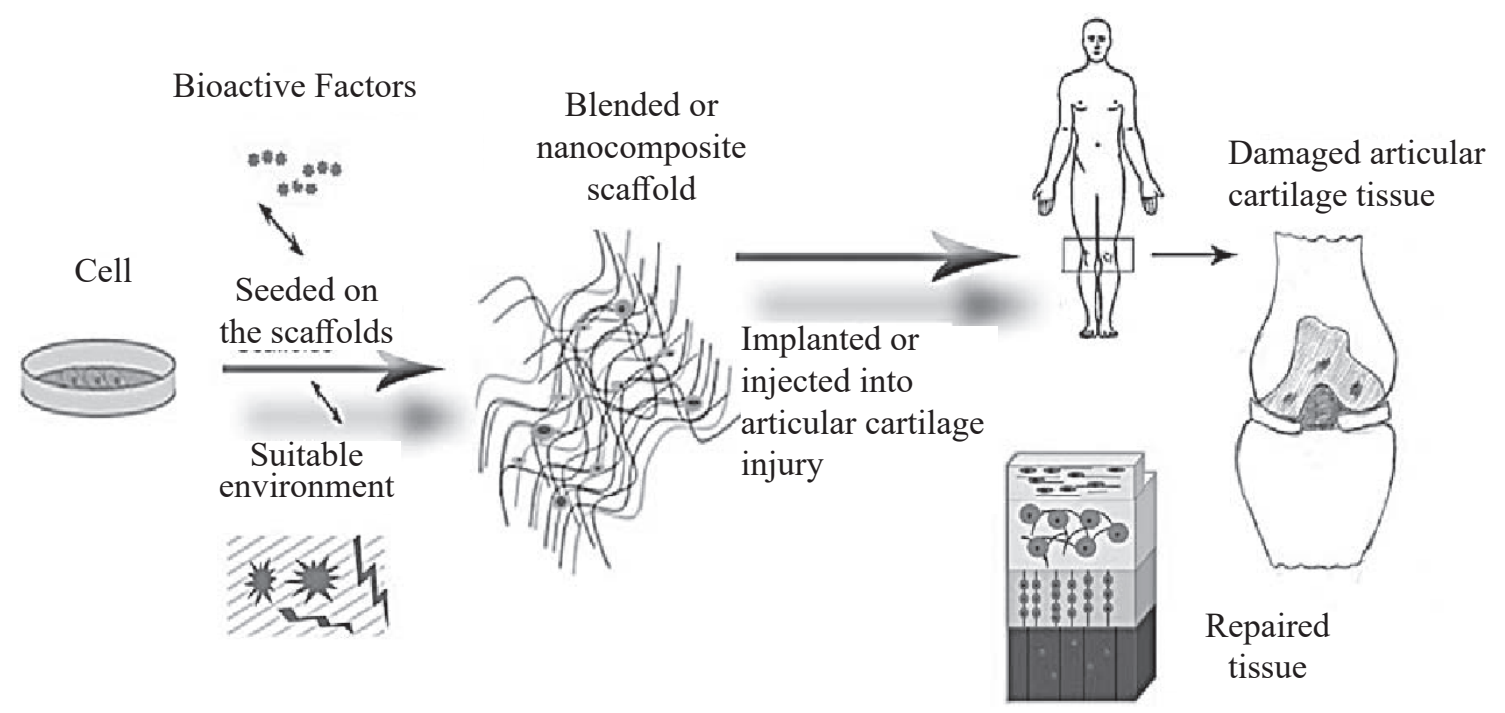

Fig. 4. Schematic representation of the articular tissue engineering procedure [83].

treatment to the nanofibers provides enhanced stability to the scaffold but at the cost of transparency. The potential of fabricated scaffolds for skin tissue regeneration was evaluated by in vitro culturing of standard cell lines i.e., fibroblast cells (L929-RFP (red fluorescent protein) and NIH-3T3) and melanocytes (B16F10). The outcomes revealed that all the fabricated nanofibrous scaffolds were non-toxic towards normal mammalian cells. In addition, healing of full-thickness wound in rats within 14 days after treatment with a nanofibrous scaffold [82].

Cartilage. Articular cartilage is a connective tissue that lines the ends of articulating bones and provides frictionless motion in diarthrodial joints whilst protecting the bones of joints from being damaged when subjected to impact and load bearing (Fig. 4). Unlike many other tissues, articular cartilage is the vascular, a neural, and a lymphatic tissue so its ability to regenerate itself remains challenging. It must be borne in mind that the engineered articular cartilage should match the mechanical functionality of the native tissue. Thus, engineered articular cartilages should have properties such as anisotropic, nonlinear, viscoelastic, and inhomogeneity [83].

Coburn et al. have demonstrated the chondrogenesity of nanofiber composite-base of PVA-methacrylate and chondroitin sulfate-methacrylate for articular cartilage repair. The low-density scaffolds were cultured with MSCs for six weeks in both chondrogenic induc- tion medium and in vivo. The presence of PVA with non-adhesive nature not only resulted in fibroblast invasion reduction in vivo but also enhanced GAG production while the presence of chondroitin sulfate in the fibers had a positive impact on increasing type II collagen synthesis and mechanical properties of tissues. Cell proliferation and differentiated into the chondrogenic lineage were confirmed by producing patterned ECM features and cartilage specific gene expression due to early cell infiltration and cartilage repair in an in vivo osteochondral defect of rat model [84]. Also, Casper et al. prepared PCL nanofiber scaffolds, with or without chitosan-coating were implanted under periosteum in 6-month-old rabbits. They demonstrated that chondrogenic cells can infiltrate PCL nanofiber scaffolds in vivo after subperiosteal implantation and produce cartilage in vitro after removal from the periosteum. This finding supports the notion that the subperiosteal space can be used as an "in vivo bioreactor" for musculoskeletal tissue engineering [85]. In another study, Jiang et al. fabricated electrospun nanofibers, made of poly ( $\varepsilon$-caprolactone)/polytetrahydrofuran (PCL-PTHF urethane) and collagen I from calfskin (termed PC), to trigger the chondrogenic differentiation of mesenchymal stem cells (MSCs) and the cartilage regeneration in vivo (Fig. 5). They identified the differential expression transcript profiles during chondrogenic differentiation. According to their result, PC nanofibers show better chondrogenic potential than the stiffer P nanofibers because of the suppression of the 

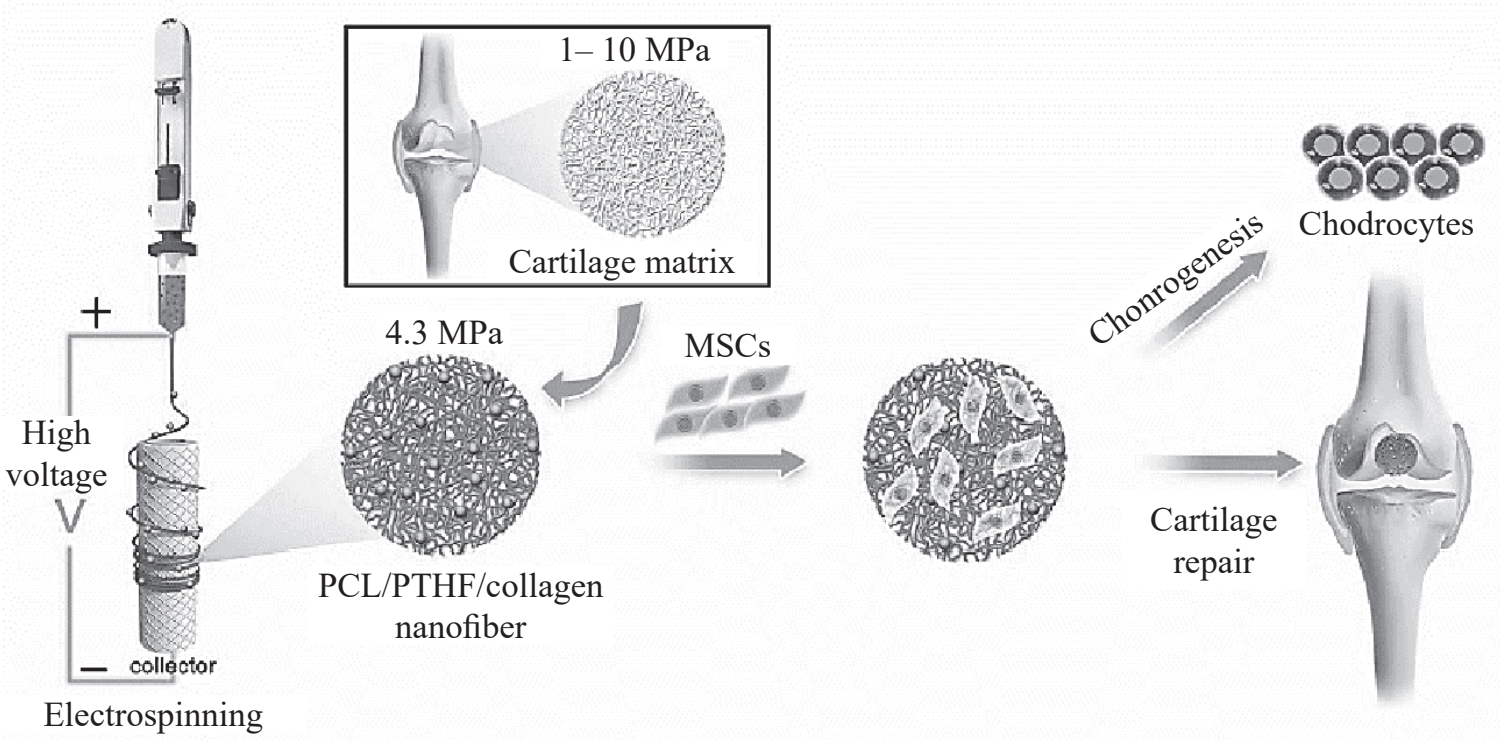

Fig. 5. Schematic description of cartilage-mimicking electrospun PC nanofiber [86].

NF-kappa B signaling pathway to suppress inflammation. Their studies provided a reference for understanding the precise role and mechanism of the mechanical cues controlling differentiation of MSCs [86].

Aliakbarshirazi et al. produced the gelatin Nano fibrous scaffolds. Their results demonstrate that the properties of Nano fibrous scaffolds which were crosslinked with glyceraldehyde have acceptable water stability, mechanical, cytotoxicity and cell adherence properties. The in vitro biological assay indicated that the gelatin nanofibers were suitable for cartilage tissue engineering [87]. Chen et al. generated a porous 3D scaffold (3DS-1) based on electrospun gelatin/ PLA nanofibers. To further improve the repairing effect of cartilage, a modified scaffold (3DS-2) crosslinked with hyaluronic acid (HA) was also fabricated. 3DS-1 possessed porous and nanofibrous structure, which could mimic the structure of natural ECM; in addition, it presented superabsorbent property and could improve the growth of chondrocytes in vitro. Compared with 3DS-1, 3DS-2 exhibited similar structure and water absorption property but higher compressive strength. Moreover, they proved that 3DS-2 could significantly repair the cartilage defect in rabbits [88]. In another investigation, Zadehnajar et al. fabricated poly $\varepsilon$-caprolactone (PCL)/gelatin with $1 \mathrm{wt} \%$ of multi-walled carbon nanotubes (MWNTs) through electrospinning method. The presence of MWNTs led to an increase in the hydrophilicity and tensile strength, while maintaining an appropriate level of porosity percentage. The bioactivity and biodegradation evaluation demonstrated that the scaffolds containing MWNTs presented more bioactivity and slower degradation rate. Cell culture study showed that the nanocomposite scaffolds did not have any cytotoxicity. According to their results, the PCL-gelatin/MWNTs nanocomposite scaffold can be appropriate for cartilage tissue engineering applications [89]. Sharifi et al. used Chondroitin sulfate and gelatin (GEL-CS) as a component of cartilage extracellular matrix to incorporated by polycaprolactone (PCL)nanofibers utilizing co-electrospinning process. The MTT anSSEM results illustrated supported cellular attachment and viability of hMSCs on scaffolds. Sulfated glycosaminoglycan secretion staining, genes expression of COL2a1 and SOX9 and also type II collagen protein approved the differentiation of seeded hMSCs to chondrocytes without using any external chondrogenic differential factor. The scaffolds containing the highest GEL-CS content (2/1) exhibit better chondrogenesis differentiation results [90]. Recently coaxial poly(glycerol sebacate) (PGS)/poly(caprolactone) (PCL) aligned nanofibers (core:PGS/shell:PCL) were fabricated using coaxial electrospinning by Silva et al. The coaxial PGS/PCL aligned nanofibers were able to promote a much more sustained release of Kartogenin (KGN) in comparison to monoaxial PCL aligned scaffolds. Importantly, KGN-loaded aligned nanofiber scaffolds promoted 

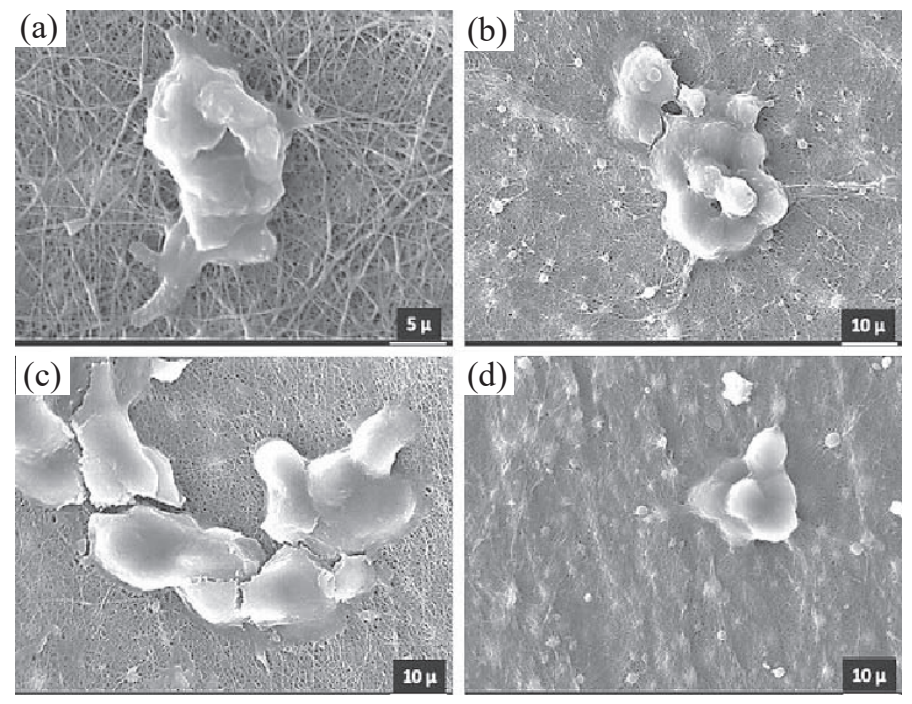

Fig. 6. Attachment of SH-SY5Y neuroblastoma cells into PCL/HA nanofibrous scaffolds, (a) PCL/HA 95 : 5, (b) PCL/HA 90 : 10, (c) PCL/HA $85: 15$, (d) PCL/HA $80: 20$ [95].

significantly the proliferation and chondrogenic differentiation of hBMSC, favoring cartilage-like ECM production and gene expression, in the absence of chondrogenic cytokine TGF- $\beta 3[1$.

Nerve. Injuries to the peripheral nervous system (PNS) are a major source of disability, impairing the ability to move muscles or to feel normal sensations. The current surgical strategies for the repair of critical nerves involving the transfer of normal donor nerve tissue from an uninjured site are frequently limited by tissue availability, risk of disease spread, secondary deformities, and potential differences in tissue structure and size, repair the damaged nervous system and restore lost function [92]. In the development of new technologies to repair the nervous system, there are two general approaches: guiding axons from the site of injury to the original synaptic site and implanting neurons to replace neurons lost as a result of injury. In some cases, only axon guidance is necessary to restore lost function, which is true (theoretically) for peripheral nerve damage. In other cases, such as spinal cord injury where loss of function is due to loss of neurons and disrupted axons, both approaches are needed. Neurite regeneration may be enough to restore function lost from severed axons, but the plasticity of native neurons alone may be insufficient to completely compensate for neurons lost at the injury site. One approach to improve axon regeneration is the design of scaffolds to act as guidance cues for neuritis [93]. Zhan et al. produced a nanofiber conduit made of blood vessel and filled with amphiphilic hydrogel of self-assembling nanofiber scaffold (SAPNS) was implanted to repair a $10 \mathrm{~mm}$ nerve gap after sciatic nerve transection. Empty blood vessel conduit was implanted serving as control. Results showed that this novel nanofiber conduit enabled the peripheral axons to regenerate across and beyond the $10 \mathrm{~mm}$ gap. Motoneuron protection, axonal regeneration, and remyelination were significantly enhanced with SAPNS scaffold treatments [94]. In other research, Entekhabi et al. designed a high porous nanofibrous scaffold using hyaluronic acid and polycaprolactone to provide ideal conditions for nerve regeneration by applying proper physicochemical and mechanical signals. In PCL/HA nanofibrous scaffolds, HA reduces the fiber diameter and increases cell adhesion and proliferation. Fig. 6, shows the morphology of SH-SY5Y cells on the scaffolds. These micrographs confirm an improved attachment of SH-SY5Y neuroblastoma cells on the PCL/HA scaffolds. Their results suggest that the blended nanofibrous scaffolds PCL/ HA $95: 5$ exhibit the most balanced properties to meet all the required specifications for neural cells and have potential application in neural tissue engineering [95].

In another research was performed by Ghasemi-Mobarakeh et al., alkaline hydrolysis of poly (E-caprolactone) (PCL) nanofibrous scaffolds was carried out for different time periods ( $1 \mathrm{~h}, 4 \mathrm{~h}$, and $12 \mathrm{~h}$ ) to increase the hydrophilicity of the scaffolds. In vitro 
cell adhesion and proliferation study was carried out after seeding nerve precursor cells (NPCs) on different scaffolds. Results of cell proliferation assay and SEM studies showed that the covalently functionalized PCL/ matrigel nanofibrous scaffolds promote the proliferation and neurite outgrowth of NPCs compared to PCL and hydrolyzed PCL nanofibrous scaffolds, providing suitable substrates for nerve tissue engineering [96]. Also, Naghavi Alhosseini et al. electrospun polyvinyl alcohol (PVA)/chitosan nanofibrous synthesized scaffolds with large pore sizes as potential matrices for nervous tissue engineering and repair. According their result, addition of chitosan to the PVA scaffolds enhances viability and proliferation of nerve cells, which increases the biocompatibility of the scaffolds. In fact, addition of a small percentage of chitosan to the PVA scaffolds proved to be a promising approach for synthesis of a neural-friendly polymeric blend [97]. Zhang et al. in a study prepared highly aligned conductive poly(L-lactic acid-co-3-caprolactone)/silk fibroin (PS)/polyaniline (PANi) nanofibers and nerve growth factor (NGF)-loaded PS/PANi nanofibers by a coaxial electrospinning technique. Their results of the viability and morphology of mouse Schwann cells on the nanofibrous meshes showed that PS-PANi-1 loaded with NGF exhibited the highest cell number after 5 days culture and the aligned nanofibers could guide cell orientation. The scaffolds loaded with NGF under electrical stimulation could effectively support PC12 neurite outgrowth and increase the percentage of neurite-bearing cells as well as the median neurite length [98]. As well as Lycium barbarum polysaccharide (LBP) was incorporated into core-shell structured nanofibrous scaffolds by Wang et al. The results indicated that the released LBP dramatically enhanced both proliferation and neuronal differentiation of PC12 cells induced by NGF. Additionally, the promotion of Schwann cells myelination and neurite outgrowth of Dorsal root ganglion (DRG) neurons were also observed on LBP loaded scaffolds by Laser scanning confocal microscopy (LSCM) with immunostaining. In summary, Lycium barbarum polysaccharide (LBP), as a drug with neuroprotection, encapsulated into electrospun nanofibers could be a potential candidate as tissue engineered scaffold for peripheral nerve regeneration [99]. Recently, Guo et al. keratose (oxidative keratin, KOS) nanoparticles-coating PVA nanofibers (KNPs/PVA) were fabricated by electrospray deposition after electrospinning and acted on neural cells.
Their result showed that KNPs/PVA nanofibers displayed better cyto-biocompatibility in terms of cell morphology, adhesion and proliferation compared with PVA nanofibers and KOS/PVA blend nanofibers. These results demonstrated that polymeric nanofibers surface modified with oxidative keratin nanoparticles have superior biocompatibility and mechanical properties, which possess great potential application for neural tissue engineering [100]. Compared with the existing PLLA/gelatin scaffold with the same component, newly nerve guidance scaffold (NGS) that made by Niu et al. is similar to the native nerve adventitia in structure and mechanical properties. In the study on the treatment of sciatic nerve injury in 24 weeks in vivo, the biomimetic PLLA/gelatin nanofiber NGS can promote Schwann cells' proliferation and migration and direct the rapid regeneration of nerve fibers, and enhance nerve function recovery [101]. Heidari et al. synthetized and evaluated PCL/gelatin/graphene nanofibers. According obtained results, this structure showed slightly higher level of biodegradation in comparison to PCL/gelatin nanofibers, as nanofibers nature is turned to more hydrophilic as a result of graphene incorporation however, the scaffold has still retained its structural integrity. Cell culture studies showed that $\mathrm{PCL} /$ gelatin/graphene nanofibrous mats provide a suitable microenvironment for cell migration, adhesion and proliferation. Furthermore, no cytotoxicity was detected in presence of graphene which would be vastly applicable in nerve tissue engineering [102].

\section{Wound Dressing}

Wound dressings promote wound healing by providing a suitable environment for tissue regeneration via the removal of exudates, protection from fluid loss, and prevention from microbial infiltration [103]. The warm, nutritious, and moist environment offered by wound beds offers a perfect condition for microbial growth. Excellent antimicrobial dressings should exhibit good broad-spectrum antimicrobial behavior, provision of a moist environment, gas permeation, and performance against antibiotic-resistant bacteria to improve healing processes [104, 105]. Electrospun nanofibers have great facility for wound dressing because of owning special characteristics, for example high surface area, and as a result electrospun nanofibers can professionally suck up exudates and regulates the wound humidity. The porosity of nanofibrous can directly impact on wound dressing 
because high porosity scaffold effectively contributes to air permeability and provide required oxygen for cell respiration, but small porosity contributes to preserving the wound from bacterial infections [106]. In addition to exhibiting the key function of moisture retention and wound protection, the electrospun nanofibers can also incorporate with therapeutic molecules and release them in a favorite and controlled mode without hampering the normal process of wound healing [107].

Kossovich et al. proposed the preparation of chitosanbased electrospun nanofibers for burn wound dressing. Burn healing is considered as one of the most critical complications of modern surgery owing to high disability and lethality after burns treatment. The prepared wound dressings were tested for IIIa and IIIb degree burns. These nanofiber dressings exhibited adequate wound ventilation, exudate absorption, and protection from infections [108]. Also, Shi et al. was introduced Trimethoxysilylpropyl octadecyldimethyl ammonium chloride (QAS) into a polycaprolactone (PCL)/gelatin hybrid in increasing concentrations to fabricate a long-acting and broad-spectrum antimicrobial micro/ nanofiber membrane as a novel wound dressing. The PCL-gelatin/QAS (PG-Q) membrane exhibited a hydrophobic surface which would help to prevent wound bed adherence with the dressing. The PG-Q membrane possessed superior antibacterial performances, including broad-spectrum and high antimicrobial activity, long-acting effectiveness, and free of drug resistance. Curcumin (Cur) was also encapsulated into PCL/gum tragacanth (GT) electrospun nanofibers for healing full thickness wound on the dorsum of rats. The antibacterial experiments indicated PCL/GT/Cur nanofibers had antibacterial ability of $99.9 \%$ against methicillinresistant Staphylococcus aureus (MRSA) and 85.14\% against extended spectrum beta lactamase (ESBL). Macroscopic investigations showed that the wounds treated with cellular and acellular PCL/GT/Cur nanofibers completely healed on 15 th day, however, the area of control group only decreased to $20.96 \pm 1.35 \%$. Simultaneously, microscopic studies demonstrated that PCL/GT/Cur scaffolds increased the collagen content in treating diabetic wounds and promoted healing process, indicating the great potential of this scaffold applied for healing of wounds in the rat models [103]. In another research, Unnithan et al. an antibacterial electrospun scaffold was prepared by electrospinning of a solution composed of dextran, polyurethane (PU) and ciprofloxacin $\mathrm{HCl}(\mathrm{CipHCl})$ drug. To confirm the cell viability, the morphological appearances of cells on composite nanofiber mats were obtained after 3 days of culture. Their results indicated that the cells interacted favorably with the scaffolds especially the drug-containing one. Moreover, the composite mat showed good bactericidal activity against both of Gram-positive and Gram-negative bacteria. Their results conclude that the introduced scaffold might be an ideal biomaterial for wound dressing applications [109]. In another investigation that performed by Zhou et al. $N$-carboxyethyl chitosan (CECS)/poly(vinyl alcohol) (PVA)/silk Fibroin (SF) nanofibers prepared by electrospinning. Indirect cytotoxicity assessment of electrospun CECS/ PVA/SF nanofiber mats with mouse fibroblasts (L929) indicated that it had good in vitro biocompatibility [110]. Also, Alippilakkotte et al. fabricated PLA/Ag nanofibers by electrospinning. The colloidal nanosilvr involved in the system were synthesized using biological reduction method from silver nitrate $\left(\mathrm{AgNO}_{3}\right)$ and bitter gourd extract (reducing agent) in diphase medium containing PLA matrix (capping agent). Their invitro analysis showed that the biofabricated PLA/Ag nanofiber (with Hemolytic percentage less than 5\%) were also cytocompatible with fibroblast cell and does not impair cell growth. An observed water vapor transmission rate (WVTR) of $2237.53 \pm 165 \mathrm{~g} / \mathrm{m} 2.24 \mathrm{~h}$ seem to provide an optimal moist environment locally to promote wound healing [111]. Recently Zhang et al. prepared astragal side IV (AS)-loaded silk fibroin/gelatin $(\mathrm{SF} / \mathrm{GT})$ nanofibers by electrospinning. Their results proved that nanofiber dressing could significantly promote angiogenesis, increase the immune function of the wound, and inhibit the scar formation via adjusting the arrangement of collagen. Preliminary mechanistic study indicated that AS-loaded SF/GT nanofiber dressing could promote wound healing by increasing the number of macrophages in the wound site, promoting vascular endothelial growth factor (VEGF) secretion and improving the local immune. Conversely, the expression level of Alpha smooth muscle actin ( $\alpha$-SMA) was inhibited by AS-loaded SF/GT nanofiber dressing, which conducive to preventing the formation of myofibroblast and inhibiting scar formation. Astragaloside IV loaded nanofiber dressing was demonstrated to be a promising therapeutic for acute trauma treatment with both healing acceleration and anti-scar effect [112]. Jatoi generated polyurethane nanofibers-based 


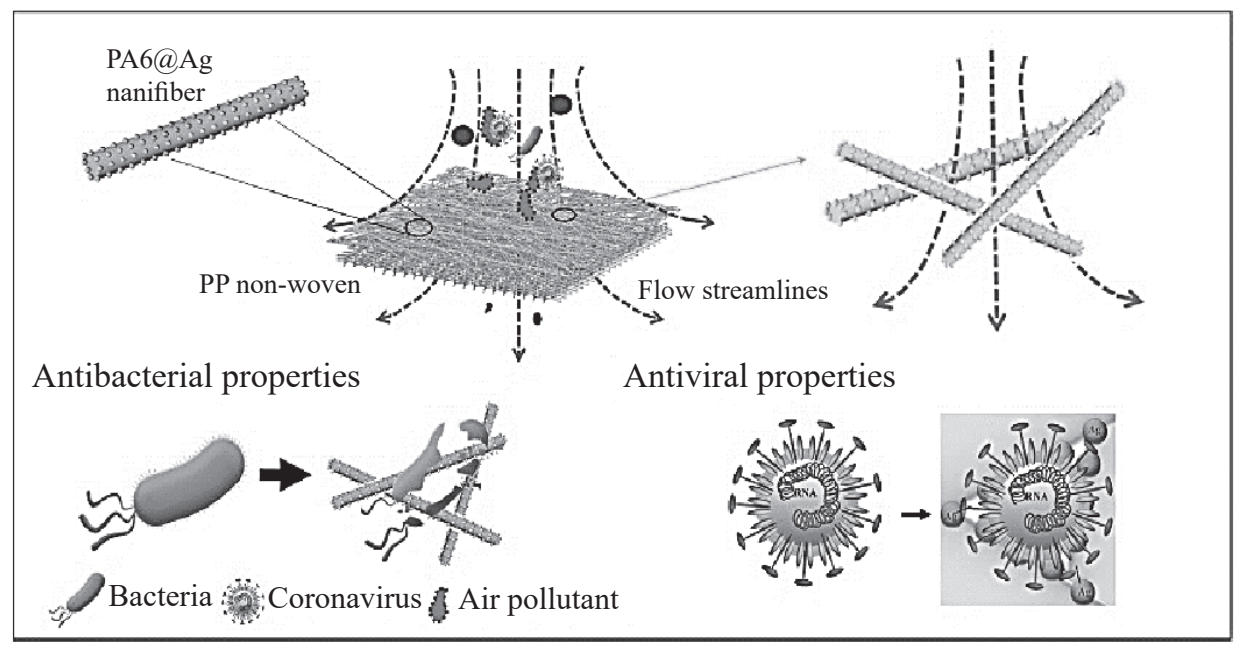

Fig. 7. Schematics showing PA6@Ag ENM as an air filter membrane with antibacterial and antiviral property [119].

nanocomposite containing silver nanoparticles/zinc oxide ( $\mathrm{ZnAg}$ ) composite nanoparticles. Both qualitative and quantitative methods were used to determine antibacterial performance of the composite nanofibers against E. coli, $S$. aureus and B. subtilis strains. The PUZnAg ${ }_{2}$ sample, which contained 8 wt $\%$ of $\mathrm{ZnAg}$, demonstrated $100 \%$ bactericidal properties against all the three test strains [113]. In another study that performed by Yin et al. a slopeing free surface electrospinning (SFSE) device used to prepare large quantities of polycaprolactone/chitosan/aloe vera (PCL/CS/ $\mathrm{AV}$ ) nanofiber membranes (NFMs). The inhibition rates of PCL/CS and PCL/CS/AV NFMs against $E$. coli were 92.92 and $96.68 \%$, respectively. It was obvious that the addition of AV in the NFMs can increase the antibacterial effect of the NFMs on E. coli. This might be due to the presence of substances such as acemannan, anthroquinones and salicylic acid in $\mathrm{AV}$, resulting in its better antimicrobial activity. The proliferation of ECs on the PCL/CS/AV NFM measured by the MTT assay exhibited good biocompatibility in 5 days, which indicated the PCL/CS/AV NFM was suitable for short-term dressing or acute wounds (1-4 days) [114]. Also, recently Haider et al. Synthesized $\mathrm{CuO}$ nanoparticles on the surface of electrospun cellulose (CE) nanofibers using alkali lignin as a reducing agent. According their findings, the $\mathrm{Cu} / \mathrm{CE}$ showed faster release $(80 \%)$ of copper ions to aqueous environment within $24 \mathrm{~h}$ and seemed to advance towards plateau for the next five days. This release behavior fits $\mathrm{Cu} / \mathrm{CE}$ nanofibrous membranes to be used as a wound dressing material. The $\mathrm{Cu} / \mathrm{CE}$ nanofibrous mats exhibited excellent antibacterial efficacy against both gram-negative Escherichia coli (E. coli) and gram-positive Staphylococcus aureus ( $S$. aureus) bacteria. NIH3T3 fibroblast cells have excellent migrating and proliferating ability on prepared nanofibrous mats. The presence of bound alkali lignin on the surface of nanofibers added a benefit of antioxidant activity [115].

\section{Facemask}

Air, widespread with bioaerosols ranging from airborne viruses, bacteria, fungi, to pollens, is associated with a variety of adverse health effects, such as allergies, infectious diseases, respiratory illnesses and cancer. Low settling velocity and minute size of the particles are the major reason for these particles to remain in the atmosphere for a longer duration than other aerosols $[116,117]$. Currently, membrane filtration is thought to be the most effective physical approach against air pollutants. Nanofiber membranes can trap most contaminants and can qualify as high-efficiency particulate air filters [118]. Recently, it was reported about fabrication of PA6/Ag and its antibacterial and antiviral property by Ju et al. (Fig. 7). The electrospun nanofibers were deposited on PP substrate, then peeled off from the roller collector. Ag nanoparticles were loaded on PA6/PP membrane by immersion method. Their results demonstrate this membrane exhibits high PM2.5 filtration efficiency of $99.99 \%$ and low pressure drop of $31 \mathrm{~Pa}$; simultaneous removal of multiple aerosol pollutants, e.g., $\mathrm{SO}_{x}$, 
$\mathrm{NO}_{x}$, methylbenzene, L-Nicotine; superior antibacterial performance against Escherichia coli (Gram negative bacteria) and Staphylococcus aureus (Gram positive bacteria), antiviral property against Porcine Delta coronavirus and not significant cytotoxicity [119].

Also, in another research, Victor et al. electrospun polyvinylidene fluoride (PVDF) blended with varying concentrations of titanium nanotubes (TNT) to result in a nanocomposite filter media. Antibacterial and zone of inhibition studies revealed that the prepared filter media was highly efficient against both Escherichia coli and Staphylococcus aureus. In this study, it was found that $15 \mathrm{wt} \%$ of the filler proved for the highest bacterial filter efficiency of $99.88 \%$ [116]. PAN/CuO nanofibers were successfully electrospun with varying concentrations of $\mathrm{CuO}$ in PAN nanofibers by Hashmi et al. From their results, it can be concluded that tensile strength has direct and linear relationship with copper oxide concentration in PAN nanofibers. Also, breathability was improved with addition of copper oxide nanoparticles. Antimicrobial test results (using disk diffusion method) proved that inhibition zone was gradually increased with increasing concentration of $\mathrm{CuO}$ in PAN nanofibers. It can be also observed that copper oxide was effective for both types (gram positive and gram negative) of bacteria which represented excellent antimicrobial feature of copper oxide. Excellent antibacterial efficacy was observed for samples with $1.00 \% \mathrm{CuO}$ concentration [120]. Swamidoss et al. fabricated an antibacterial filter using poly vinylidene fluoride nanofibres by electrospinning method blended with silver nanoparticles $\left(\mathrm{AgNO}_{3}\right)$ of varying weight percentages of filler. Polypropylene non-woven substrate was used as base material for collecting the nanofibres. It also acted as a barrier to protect the fibres. Zone of inhibition test showed that pure PVDF has minimum amount of antibacterial activity due to its inbuilt electrostatic property on both gram positive and gramnegative bacteria. Addition of varying silver concentrations the antibacterial activity increased several orders against microorganisms and 15 wt \% of silver showed maximum antibacterial activity. This research shows the bacterial filtration efficiency for the prepared PVDF-Ag nanofibres as $99.86 \%$ [121].

\section{CONCLUSIONS}

In the recent decade, many studies have proven the extreme potential of nanofibers in front of current chal- lenges in the medical and healthcare field. The remarkable properties make nanofibers ideal candidates for a wide range of biomedical and healthcare applications, especially the antimicrobial treatment of bacteria-related biofilms, orthopedic implant-related infections, tissue scaffolds, and wound dressings. Therefore, nanofibers are a promising solution to address these challenges. They are precisely like the native extracellular matrix (ECM) and support cell proliferation, adhesion, tendency to preserve their phenotypic shape and directed growth according to the nanofiber direction. Some new techniques, such as electrospinning, 3D printing, and combination molding techniques, have been developed to control the properties of scaffolds, such as a uniform and porous 3D structure, interconnected pores, and proper mechanical properties. By controlling the electrospinning solution, the use of different collecting setups or post-processing the scaffolds, controllable 3D structures with high porosities, and uniform micro- and macro-pore sizes can be achieved. Electro-spinning has the exceptional capability of generating nano-fibers by the use of different materials in different fibrous assemblies. This review outlined some of the recent work in tissue scaffold applications on skin, bone, cartilage, vascular, neural tissues, wound dressing and facemasks. In each application, some of the background principles on the role of nanofiber in performing the intended function have been discussed. Throughout this review, new insights for biomedical applications have been addressed, focusing on the promising benefits of employing electrospun nanofibers. Electrospun nanofibers have many advantages for their application in the field of tissue engineering. (i) high surface-to-volume ratios, (ii) easy fabrication and functionalization, (iii) low cost, (iv) controllability of nanofiber properties, (v) excellent biocompatibility and biodegradability. It should be noted there are still some shortcomings of nanofibers for the application in the field of tissue engineering. (i) The pore size of electrospun nanofibrous scaffolds is too small, which is not enough for cell infiltration growth. (ii) The mechanical properties of electrospun nanofibrous scaffolds are generally not ideal for hard tissue regeneration. Necessary consideration or treatments are needed for the application process. (iii) In vivo degradation performance of electrospun nanofibrous scaffolds is difficult to control. But in general, with the development of science and technology, we believe that the clinical application of electrospun nanofiber scaffolds will be achieved in the future. Hence, The future challenges of 
nanofibers can be summarized as follows: (i) Novel nanofiber fabrication techniques are still needed to move from nanofiber production from laboratory scale to commercial and industrial settings, (ii) Nanofibers are still being required more attempts to achieve the most ideal nanofiber properties (e.g., composition, diameter, morphology, pore size) for effective healthcare and biomedical applications in the market scale.

\section{ABBREVIATIONS}

ECM extracellular matrix

PCL poly(e-caprolactone)

e-PTFE expanded polytetrafluoroethylene

EC Endothelial cells

SMC smooth muscle cells

CS-CTS chitosan

HUVEC human umbilical vein endothelial cells

TP Tecophilic

gel gelatin

HA aligned hyaluronan

PLLA poly-L-lactic acid

TPU synthetic thermoplastic polyurethane

EC Ethyl Cellulose

HAp hydroxyapatite

PLLA poly-L-lactide

CT computed tomography

PLGA poly(lactic-co-glycolic acid)

$\mathrm{BC}$ bacterial cellulose

CNF carbon nanofiber

AP-g-GA aniline pentamer-graft-gelatin

MSN mesoporous silica nanoparticle

ALP Alkaline phosphatase

PLA polylactic acid

TSF Tussah silk fibroin

ECHNN electrospun cellulose/nano-HA nanocomposite nanofibers

HDFCs human dental follicle cells

PDA polydopamine

GO graphene oxide

PU polyurethane

RGD Arg-Gly-Asp peptide

CA cellulose acetate

ST Starch
SPI soy protein isolate

RFP red fluorescent protein

PGS poly(glycerol sebacate

KGN Kartogenin

NGS nerve guidance scaffold

NFMs nanofiber membranes

AV aloe vera

GAG glycosaminoglycan

TFE trifluoroethanol

SDF standard deviation of fiber diameter

MFD mean fiber diameter

PVA polyvinyl alcohol

PHB polyhydroxybutyrate

$\mathrm{HaCaT}$ human keratinocyte cell line

SF silk fibroin

ESF electrospun silk fibroin

SLE Salt leaching electrospining

CPCL caprolactone

PTHF polytetrahydrofuran

MSCs mesenchymal stem cells

3DS 3D scaffold

HA hyaluronic acid

MWNTs multi-walled carbon nanotubes

PNS peripheral nervous system

SAPNS self-assembling nanofiber scaffold

NPCs nerve precursor cells

PS poly(L-lactic acid-co-3-caprolactone)/silk fibroin

PANi polyaniline

NGF nerve growth factor

LBP Lycium barbarum polysaccharide

DRG Dorsal root ganglion

LSCM Laser scanning confocal microscopy

KOS oxidative keratin

KNPs Keratose nanoparticles

QAS Trimethoxysilylpropyl octadecyldimethyl ammonium chloride

Cur Curcumin

GT gum tragacanth

MRSA methicillin-resistant Staphylococcus aureus

ESBL extended spectrum beta lactamase

CECS N-carboxyethyl chitosan

WVTR water vapor transmission rate 


$\begin{array}{ll}\text { AS } & \text { astragal side IV } \\ \text { VEGF } & \text { vascular endothelial growth factor } \\ \alpha \text {-SMA } & \text { Alpha smooth muscle actin } \\ \text { PP } & \text { Polypropylene } \\ \text { PA6 } & \text { polyamide } 6 \\ \text { PVDF } & \text { Polyvinylidene fluoride } \\ \text { TNT } & \text { titanium nanotubes }\end{array}$

\section{CONFLICT OF INTERESTS}

The authors declare that they have no conflicts of interest requiring disclosure in this article.

\section{REFERENCES}

1. Rošic, R., Kocbek, P., Pelipenko, J., et al., Acta Pharmaceutica, 2013, vol. 63, no. 3, pp. 295-304.

2. Rasouli, R., Barhoum, A., Bechelany, M., and Dufresne, A., Macromol. Biosci., 2019, vol. 19, no. 2, p. 1800256.

https://doi.org/10.1002/mabi.201800256

3. Sridhar, R., Venugopal, J.R., Sundarrajan, S., et al., J. Drug Delivery Sci. Technol., 2011, vol. 21, no. 6, pp. $451-468$.

4. Leung, V. and Ko, F., Polym. Adv. Technol, 2001, vol. 22, no. 3, pp. 350-365.

https://doi.org/10.1002/pat.1813

5. Akhgari, A., Shakib, Z., and Sanati, S., Nanomedicine, 2017, vol. 4, no. 4, pp. 197-207.

6. Mo, X., Sun, B., Wu, T., and Li, D., Electrospinning: Nanofabrication and Applications, William Andrew Publishing, 2019.

7. Abudula, T., Mohammed, H., Joshi Navare, K., et al., ACS Appl Bio Mater, 2019, vol. 2, no. 3, pp. 952-969. https://doi.org/10.1016/j.jclepro.2017.01.004

8. Asmatulu, R. and Khan, W.S., Synthesis and Applications of Electrospun Nanofibers, 2019, pp. 41-61.

9. Ashammakhi, N., Wimpenny, I., Nikkola, L., and Yang, Y., J. Biomed. Nanotechnol., 2009, vol. 5, no. 1, pp. 1-19.

10. Zahmatkeshan, M., Adel, M., Bahrami, S, et al., Handbook of Nanofibers, 2018.

https://doi.org/10.1007/978-3-319-53655-2

11. Cheng, F., Tao, Z., Liang, J., and Chen, J., Chem. Mater., 2008, vol. 20, no. 3, pp. 667-681.

https://doi.org/10.1021/cm702091q
12. Wang, J. and Nain, A.S., Langmuir, 2014, vol. 30, no. 45, pp. 13641-13649. https://doi.org/10.1021/la503011u

13. Samimi Gharaie, S., Habibi, S., and Nazockdast, H., J. Text. Fibrous Mater., 2018, vol. 1, pp. 1-8. https://doi.org/10.1177/2515221118769324

14. Rim, N.G., Shin, C.S., and Shin, H., Biomed. Mater, 2013, vol. 8, no. 1, p. 014102.

15. Taghavi, S.M., and Larson, R.G., Phys. Rev. E, 2014, vol.89, no. 2, p. 023011.

16. Sarkar, K., Gomez, C., Zambrano, S., et al., Mater. Today, 2010 , vol. 13 , no. 11, pp. 12-14. https://doi.org/10.1016/S1369-7021(10)70199-1

17. Koosha, K., Habibi, S., and Talebian, A., Russ. J. Appl. Chem., 2017, vol. 90, no. 10, pp. 1640-1647.

18. Talebian, A., Mansourian, A., Mater. Today: Proc., 2017, vol.4, no. 7, pp. 7065-7069.

19. Elhami, M., Habibi, S.J., Vinyl Add. Tech., 2021, vol. 27, no. 1, pp. 89-96.

20. Habibi, S., Saket, M., Nazockdast, H., and Hajinasrollah, K., J. Text. Inst., 2019, vol. 110, no. 11, pp. 16721677.

https://doi.org/10.1080/00405000.2019.1613029

21. Hajinasrollah, K., Habibi, S., and Nazockdast, H., J. Eng. Fibers Fabr., 2019, vol. 14, pp. 1-9.

22. US Patent 1699615A, 1929.

23. Sridhar, R., Venugopal, J.R., Sundarrajan, S., et al., J. Drug Delivery Sci. Technol., 2011, vol. 21, no. 6, pp. 451-468.

24. Szentivanyi, A.L., Zernetsch, H., Menzel, H., and Glasmacher, B., Int. J. Artif. Organs, 2011, vol. 34, no. 10, pp. 986-997.

25. Habibi, S. and Hajinasrollah, K., Russ. J. Appl. Chem., 2018, vol. 91, no. 5, pp. 877-881. https://doi.org/10.1134/S1070427218050191

26. Khirandish, M., Borhani, S., Mallakpour, S., and Youssefi, M., IJFTR, 2016, vol. 41, pp. 373-379.

27. Pang, Z., Nie, Q., Yang, J., et al., IJFTR, 2017, vol. 42, pp. 138-144.

28. Suresh, S.J., Nanosci. Nanotechnol., 2013, vol. 3, no. 3, pp. $62-74$.

29. Qamoshi, K. and Rasuli, R., Appl. Phys. A, 2016, vol. 122, no. 9, p. 788.

30. Ma, H. and Hsiao, B.S., Filtering Media by Electrospinning, 2020, Switzerland: Springer International Publish- 
ing, 2018, pp. 25-46.

31. Dotto, G.L, Santos, J.M.N., Tanabe, E.H., et al., J. Cleaner Prod., 2017, vol. 144, pp. 120-129. https://doi.org/10.1016/j.jclepro.2017.01.004

32. Ramakrishna, S., Jose, R., Archana, P.S., et al., J. Mater. Sci., 2010, vol. 45, no. 23, pp. 6283-6312. https://doi.org/10.1007/s10853-010-4509-1

33. Kim, B.C., Nair, S., Kim, J., et al., J. Nanotechnol., 2005, vol. 16 , no. 7 , p. 382 .

34. Kai, D., Liow, S.S., and Loh, X.J., Mater. Sci. Eng. C, 2014, vol. 45, pp. 659-670. https://doi.org/10.1016/j.msec.2014.04.051

35. Huang, Z.M., Zhang, Y.Z., Kotaki, M., and Ramakrishna, S., Compos. Sci. Technol., 2003, vol. 63, no. 15, pp. 2223-2253.

36. Bedeloğlu, A.C., Bhullar, S.K., Borazan, I., et al., IJFTR, 2017, vol. 42, no. 1, pp. 38-42.

37. Ahadian, S., Obregón, R., Ramón-Azcón, J., et al., $\mathrm{Na}$ nofiber Composites for Biomedical Applications, 2017, pp. 507-528.

https://doi.org/10.1016/B978-0-08-100173-8.00020-X

38. Jannesari, M., Varshosaz, J., Morshed, M., and Zamani, M., Int. J. Nanomed., 2011, vol. 6, p. 993. https://doi.org/10.2147/IJN.S17595

39. Khadka, D.B. and Haynie, D.T., Nanomed. Nanotechnol. Biol. Med., 2012, vol. 8, pp. 1242-1262. https://doi.org/10.1016/j.nano.2012.02.013

40. Al-Enizi, A., Zagho, M., and Elzatahry, A., J. Nanomater., 2018, vol. 8, no. 4, p. 259. https://doi.org/10.3390/nano8040259

41. Zamani, R., Aval, S.F., Pilehvar-Soltanahmadi, Y., et al., Drug Res., 2018, vol. 68, no. 8, pp. 425-435. https://doi.org/10.1055/s-0043-125314

42. Alharbi, H.F., Luqman, M., Khalil, K.A., et al., Eur. Polym. J., 2018, vol. 98, pp. 483-491. https://doi.org/10.1016/j.eurpolymj.2017.11.052

43. Yao, Y., Wang, J., Cui, Y., et al., Acta Biomater., 2014, vol. 10, no. 6, pp. 2739-2749. https://doi.org/10.1016/j.actbio.2014.02.042

44. Ye, L., Cao, J., Chen, L., et al., J. Biomed. Mater. Res. Part A, 2015, vol. 103, no. 12, pp. 3863-3871.

45. Lee, K.Y. and Mooney, D.J., Prog. Polym. Sci., 2012, vol. 37, no. 1, pp. 106-126. https://doi.org/10.1016/j.progpolymsci.2011.06.003

46. Jiang, Y.C., Jiang, L., Huang, A., et al., Mater. Sci. Eng., C, 2017, vol. 71, pp. 901-908. https://doi.org/10.1016/j.msec.2016.10.083

47. Pektok, E., Nottelet, B., Tille, J.C., et al., Circulation, 2008, vol. 118 , no. 24, pp. 2563-2570.

48. Ju, Y.M., San Choi, J., Atala, A., et al., Biomater., 2010, vol. 31, no. 15 , pp. 4313-4321.

https://doi.org/10.1016/j.biomaterials.2010.02.002

49. He, Q., Gong, K., Ao, Q., et al., J. Biomater. Appl., 2013, vol. 27, no. 8, pp. 1032-1045. https://doi.org/10.1177/0885328211432487

50. Du, F., Wang, H., Zhao, W., et al., Biomater., 2012, vol. 33, no. 3, pp. 762-770. https://doi.org/10.1016/j.biomaterials.2011.10.037

51. Vatankhah, E., Prabhakaran, M.P., Semnani, D., et al., Biopolymers, 2014, vol. 101, no. 12, pp. 1165-1180. https://doi.org/10.1002/bip.22524

52. Yuan, H., Qin, J., Xie, J., et al., Nanoscale, 2016, vol. 8, no. 36, pp. 16307-16322.

53. Yu, E, Mi, H.Y., Zhang, J. et al., J. Biomed. Mater. Res. Part A, 2018, vol. 106, no. 4, pp. 985-996. https://doi.org/10.1002/jbm.a.36297

54. Aydogdu, M.O., Chou, J., Altun, E., et al., Inter. J. Polym. Mater. and Polym. Biomater., 2019, vol. 68, no. 5, p. 243-255. https://doi.org/10.1080/00914037.2018.1443930

55. Kong, X., He, Y., Zhou, H., et al., Nanoscale Res. Lett., 2021 , vol. 16, no. 1, pp. 1-11.

56. Liu, Q., Ying, G., Jiang, N., et al., Med. Novel Technol. Devices., 2021.

57. Wen, Y., Xun, S., Haoye, M., et al., Biomater. Sci., 2017, vol. 5, no. 9, pp. 1690-1698.

58. Kaoud, H.A., Tissue Regeneration, 2018.

59. Yu, C.C., Chang, J.J., Lee, Y.H., et al., Mater. Lett., 2013, vol. 93, pp. 133-136. https://doi.org/10.1016/j.matlet.2012.11.040

60. Lai, W.Y., Feng, S.W., Chan, Y.H., et al., Polymers, 2018, vol. 10 , no. 7 , p. 804 . https://doi.org/10.3390/polym10070804

61. Meng, Z.X., Wang, Y.S., Ma, C., et al., Mater. Sci. Eng., C, 2010, vol. 30, no. 8, pp. 1204-1210. https://doi.org/10.1016/j.msec.2010.06.018

62. Wan, Y., Zuo, G., Yu, F., et al., Surf. Coat. Technol., 2011, vol. 205, nos. 8, 9, pp. 2938-2946.

63. Frohbergh, M.E., Katsman, A., Botta, G.P., et al., Biomater., 2012, vol. 33, no. 36, pp. 9167-9178. https://doi.org/10.1016/j.biomaterials.2012.09.009

64. Liu, Y., Cui, H., Zhuang, X., et al., Acta Biomater., 2014, 
vol. 10 , no. 12 , pp. 5074-5080.

https://doi.org/10.1016/j.actbio.2014.08.036

65. Li, K., Sun, H., Sui, H., et al., Rsc. Advances, 2015, vol. 5, no. 23 , pp. 17541-17549.

66. Shao, W., He, J., Han, Q., et al., Mater. Sci. Eng., C, 2016, vol. 67, pp. 599-610.

https://doi.org/10.1016/j.msec.2016.05.081

67. Ao, C., Niu, Y., Zhang, X., et al., Int. J. Biol. Macromol., 2017, vol. 97, pp. 568-573.

68. Ghorbani, F., Zamanian, A. and Aidun, A., J. Appl. Polym. Sci., 2019, vol. 136, no. 24, pp. 47656-47664.

69. Wang, J., Yang, M., Zhu, Y., et al., Adv. Mater., 2014, vol. 26, no. 29, pp. 4961-4966.

70. Ghavimi, M.A., Negahdari, R., Bani Shahabadi, A., et al., Eurasian Chemical Communications, 2020, vol. 2, no. 1, pp. 122-127.

71. Chen, P., Liu, L., Pan, J., et al., Mater. Sci. Eng., C, 2019, vol. 97, pp. 325-335. https://doi.org/10.1016/j.msec.2018.12.027

72. Vig, K., Chaudhari, A., Tripathi, S., et al., Int. J. Mol. Sci., 2017 , vol. 18 , no. 4 , p. 789. https://doi.org/10.3390/ijms18040789

73. Guarino, V., Gloria, A., Raucci, M.G., and Ambrosio, L., Polymers, 2012, vol. 4, no. 3, pp. 1590-1612. https://doi.org/10.3390/polym4031590

74. Pezeshki-Modaress, M., Mirzadeh, H., and Zandi, M., Mater. Sci. Eng., C, 2015, vol. 48, pp. 704-712. https://doi.org/10.1016/j.msec.2014.12.023

75. Lin, H.Y., Chen, H.H., Chang, S.H., and Ni, T.S., J. Biomater. Sci., Polym. Ed., 2013, vol. 24, no. 4, pp. 470-484. https://doi.org/10.1080/09205063.2012.693047

76. Asran, A.S., Razghandi, K., Aggarwal, N., et al., Biomacromol., 2010, vol. 11, no. 12, pp. 3413-3421. https://doi.org/10.1021/bm100912v

77. Shalumon, K.T., Sathish, D., Nair, S.V., et al., J. Biomed. Nanotechnol., 2012, vol. 8, no. 3, pp. 405-416. https://doi.org/10.1166/jbn.2012.1395

78. Park, Y.R., Ju, H.W., Lee, J.M., et al., Int. J. Biol. Macromol., 2016, vol. 93, pp. 1567-1574.

79. Levengood, S.L., Erickson, A.E., Chang, F.C., and Zhang, M., J. Mater. Chem. B., 2017, vol. 5, no. 9, pp. 1822-1833.

80. Abdul Khodir, W., Abdul Razak, A., Ng, M., et al., J. Function. Biomater., 2018, vol. 9, no. 2, pp. 36-44.

81. Movahedi, M., Asefnejad, A., Rafienia, M., et al., Int. J. Biol. Macromol., 2020, vol. 146, pp. 627-637. https://doi.org/10.1016/j.ijbiomac.2019.11.233

82. Varshney, N., Sahi, A.K., Poddar, S., et al., Int. J. Biol. Macromol., 2020, vol. 160, pp. 112-127.

https://doi.org/10.1016/j.ijbiomac.2020.05.090

83. Doulabi, A., Mequanint, K., and Mohammadi, H., Mater., 2014, vol. 7, no. 7, pp. 5327-5355.

https://doi.org/10.3390/ma7075327

84. Coburn, J.M., Gibson, M., Monagle, S., et al., Proc. Natl. Acad. Sci. U.S.A., 2012, vol. 109, no. 25, pp. 1001210017.

https://doi.org/10.1073/pnas.1121605109

85. Casper, M.E., Fitzsimmons, J.S., Stone, J.J., O’Driscoll, S.W., and Reinholz, G.G., Osteoarthr. Cartil., 2010, vol. 18, no. 7, pp. 981-991. https://doi.org/10.1016/j.joca.2010.04.009

86. Jiang, T., Kai, D., Liu, S., et al., Biomater., 2018, vol. 178, pp. 281-292.

https://doi.org/10.1016/j.biomaterials.2018.06.023

87. Aliakbarshirazi, S. and Talebian, A., Mater. Today: Proc., 2017, vol. 4, no. 7, pp. 7059-7064. https://doi.org/10.1016/j.matpr.2017.07.038

88. Chen, W., Chen, S., Morsi, Y., et al., ACS Appl. Mater. Interfaces, 2016, vol. 8, no. 37, pp. 24415-24425.

89. Zadehnajar, P., Akbari, B., Karbasi, S., and Mirmusavi, M.H., Int. J. Polym. Mater. and Polym. Biomater., 2019, pp. 1-12.

90. Sharifi, F., Irani, S., Azadegan, G., et al., Bioact. Carbohydr. Dietary Fibre, 2020, vol. 22, p. 100215. https://doi.org/10.1016/j.bcdf.2020.100215

91. Silva, J.C., Udangawa, R.N., Chen, J., et al., Mater. Sci. Eng., C, 2020, vol. 107. p. 110291.

https://doi.org/10.1016/j.msec.2019.110291

92. Navarro, X., Rodriguez, F.J., Ceballos, D., and Verdu, E., Med. Biol. Eng. Comput., 2003, vol. 41, no. 2, pp. 220226.

https://europepmc.org/article/med/10959242

93. Miller, R.J., Chan, C.Y., Rastogi, A., et al., J. Biomater. Sci., Polym. Ed., 2018, vol. 29, no. 13, pp. 1625-1642.

94. Zhan, X., Gao, M., Jiang, Y., et al., Nanomed. Nanotechnol. Biol. Med., 2013, vol. 9, no. 3, pp 305-315.

95. Entekhabi, E., Nazarpak, M.H., Moztarzadeh, F., and Sadeghi, A., Mater. Sci. Eng., C, 2016, vol. 69, pp. 380387.

https://doi.org/10.1016/j.msec.2016.06.078

96. Ghasemi-Mobarakeh, L., Prabhakaran, M.P., Morshed, M., et al., Mater. Sci. Eng., C, 2010, vol. 30, no. 8, 
pp. 1129-1136.

97. Alhosseini, S.N., Moztarzadeh, F., Mozafari, M., et al., Int. J. Nanomed., 2012, vol. 7, pp. 25-34. https://doi.org/10.2147/IJN.S25376

98. Zhang, J., Qiu, K., Sun, B., et al., J. Mater. Chem. B, 2014, vol. 2, no. 45, pp. 7945-7954.

99. Wang, J., Tian, L., He, L., et al., Sci. Rep., 2018, vol. 8, no. 1, pp. 8669-8682.

100. Guo, T., Yang, X., Deng, J., et al., J. Mater. Sci.-Mater. Med., 2019, vol. 30, no. 1, p. 9.

101. Niu, Y., Stadler, F.J. and Fu, M., Mater. Sci. Eng., C, 2021, vol. 121.

102. Heidari, M., Bahrami, S.H., Ranjbar-Mohammadi, M., et al., Mater. Sci. Eng., C, 2019, vol. 103, p. 109768 https://doi.org/10.1016/j.msec.2019.109768

103. Shi, R., Geng, H., Gong, M., et al., J. Colloid Interface Sci., 2018, vol. 509, pp. 275-284. https://doi.org/10.1016/j.jcis.2017.08.092

104. Field, C.K. and Kerstein, M.D., Am. J. Surg., 1994, vol. 167, no. 1, pp. S2-S6.

105. Agrawal, A. and Purwar, R., IJFTR, 2018, vol. 43, no. 1, pp. 104-111. http://nopr.niscair.res.in/handle/123456789/43993

106. Tian, L., Prabhakaran, M.P., Ding, X., Kai, D., and Ramakrishna, S., J. Mater. Sci., 2012, vol. 47, no. 7, pp. 3272-3281.

107. Pilehvar-Soltanahmadi, Y., Dadashpour, M., Mohajeri, A., et al., Mini Reviews in Medicinal Chemistry, 2018, vol. 18, no. 5, pp. 414-427.

108. Kossovich, L.Y., Salkovskiy, Y., and Kirillova, I.V., 6th World Congress of Biomechanics, Berlin: Springer, 2010.

109. Unnithan, A.R., Barakat, N.A., Pichiah, P.T., et al., Carbohydr. Polym., 2012, vol. 90, no. 4, pp. 1786-1793.
110. Zhou, Y., Yang, H., Liu, X., et al., Int. J. Biol. Macromol., 2013, vol. 53, pp. 88-92.

111. Alippilakkotte, S., Kumar, S., and Sreejith, L., Colloids Surf. A., 2017, vol. 529, pp. 771-782.

112. Zhang, D., Li, L., Shan, Y., and Gao, J.J.. Drug Delivery Sci. Technol., 2019, vol. 52, pp. 272-281. https://doi.org/10.1016/j.jddst.2019.04.021

113. Jatoi, A.W., Composites Communications, 2020, vol. 19, pp. 103-107.

114. Yin, J. and Xu, L., Int. J. Biol. Macromol., 2020, vol. 160, pp. 352-363.

https://doi.org/10.1016/j.ijbiomac.2020.05.211

115. Haider, M.K., Ullah, A., Sarwar, M.N., et al., Int. J. Biol. Macromol., 2021, vol. 173, pp. 315-26. https://doi.org/10.1016/j.ijbiomac.2021.01.050

116. Victor, F.S., Kugarajah, V., Bangaru, M., Ranjan, S., et al., Environ. Sci. Pollut. Res., 2021, pp. 1-14. https://doi.org/10.1007/s11356-021-13202-3

117. Mohraz, M.H., Golbabaei, F., Yu, I.J., et al., Int. J. Environ. Sci. Technol., 2019, vol. 16, no. 2, pp. 681-694.

118. Canalli Bortolassi, A.C., Guerra, V.G., Aguiar, M.L., et al., Nanomaterials, 2019, vol. 9, no. 12, pp. 17401755.

https://doi.org/10.3390/nano9121740

119. Ju, Y., Han, T., Yin, J., et al., Science of the Total Environment, 2021, vol. 777, p. 145768

https://doi.org/10.1016/j.scitotenv.2021.145768

120. Hashmi, M., Ullah, S., and Kim, I.S., Curr. Res. Biotechnol., 2019, pp. 1-10.

https://doi.org/10.1016/j.crbiot.2019.07.001

121. Felix Swamidoss, V., Bangaru, M., Nalathambi, G., et al., Aerosol Sci. Technol., 2019, vol. 53, no. 2, pp. 196-206. https://doi.org/10.1080/02786826.2018.1554892 